\title{
National innovation systems, capabilities and economic development
}

\author{
Jan Fagerberg \\ And \\ Martin Srholec \\ Centre for Technology, Innovation and Culture, \\ University of Oslo
}

Version of October $24^{\text {th }} 2007$

TIK Working Paper on Innovation Studies 20071024

\begin{abstract}
This paper focuses on the role of capabilities for economic development. In recent years data on different aspects of development have improved a lot. This provides new opportunities for in-depth research on capabilities and their measurement. The analysis, based on a factor analysis on 25 indicators and 115 countries from the 1992-2004 period, identifies four different types of "capabilities"; the development of the "innovation system", the quality of "governance", the character of the "political system" and the degree of "openness" of the economy. Innovation systems and governance are shown to be of particular importance for economic development.
\end{abstract}

Keywords: national innovation system, capabilities, governance, development.

JEL: E11, F43, O30.

\footnotetext{
* Earlier versions of this paper were presented the UNIDO Industrial Development Report 2005 Workshop in Vienna, 11-12 May 2005, the 11th International Joseph A. Schumpeter Society Conference in Nice/Sophia Antipolis, 21-24 June 2006 and the 4th Globelics Conference, Trivandrum, 4-7 October 2006. We wish to thank the participants for useful suggestions. All usual caveats apply. E-mail: jan.fagerberg@tik.uio.no.
} 


\section{Introduction}

Not long ago most economists believed that differences in development levels across countries were to be explained by one single factor, namely differences in the amount of accumulated capital per worker (Solow, 1956, see Fagerberg, 1994 for an overview). However, from the 1960s onwards the idea that differences in development are mainly caused by technological differences received increasing support (Gershenkron 1962, Abramovitz 1986). This view was, of course, consistent with the perspective on growth developed by Joseph Schumpeter (Schumpeter, 1934, 1943), and during the 1980s a lot of new work on cross-country differences in levels of development and growth performance inspired by this perspective emerged (Freeman, et al., 1982; Fagerberg, 1987, 1988; Dosi et al., 1990; Verspagen, 1991). The focus on technology as the driving force of growth and development has also been taken up by advocates of the so-called "new growth theory" (Lucas, 1988; Romer, 1990; Aghion and Howitt, 1992).

Authors that emphasize the crucial role of technology for development tend to stress that catching up in technology is by no means a free ride. According to this perspective, countries that do not succeed in developing appropriate technological capabilities and other complementary factors should be expected to continue to lag behind. Concepts such as "social capability" (Ohkawa and Rosovsky, 1974; Abramovitz, 1986) "absorptive capacity" (Cohen and Levintal, 1990), "technological capability" (Kim, 1997), "innovation system" (Lundvall, 1992; Nelson, 1993; Edquist, 1997) and "innovative capacity" (Furman et al., 2002), have been suggested and a burgeoning empirical literature has emerged focusing on these aspects of development (see Fagerberg and Godinho, 2004; Archibugi and Coco, 2005 for overviews). However, as we show in the next section of this paper, there is a big overlap 
between several of these concepts and the relationship between conceptual and empirical work in this area is often weak.

To some extent this reflects that, until recently, there was generally a lack of appropriate data that could be used to put numbers on the various aspects emphasized by the theoretical literature. But in recent years the quality and availability of data on different aspects of development have improved a lot, and this might give researchers a new opportunity for investigating the reasons behind the large differences in economic performance in more depth. In the third section of the paper we therefore, following the theoretical work in this area, proceed to an empirical analysis of the capabilities needed to succeed in development. Rather than picking individual indicators and combine them in an essentially arbitrary way we follow Adelman and Morris (1965, 1967) and Temple and Johnson (1998) in mapping the most central elements with the help of factor analysis. The results, presented in the fourth section of the paper, clearly illustrate the multidimensional character of "capabilities", resulting in four different dimensions, which we label "innovation system", "governance", "political system" and "openness", respectively. Finally, we explore the extent to which cross-country differences in capabilities may help us understand why some countries excel economically while other continue to be poor. We show that what matters most for success is a well-functioning innovation system and good governance. 


\section{Taking stock of the literature}

Intuitively, most people easily accept the idea that technology and economic development are intimately related. However, economic theorists have faced great problems in incorporating technology into their analysis. This had to do with a particular view on technology that had come to dominate economics; namely as a body of information, freely available to all interested, that can be used over and over again (without being depleted). Arguably, if this is what technology is about, it should be expected to benefit everybody all over the globe to the same extent, and cannot be invoked to explain differences in development.

It is understandable, therefore, that the first systematic attempts to conceptualise the relationship between technology and development did not come from the economics mainstream. It was the economic historian Alexander Gerschenkron who came to set the stage for much of the subsequent literature (Gerschenkron, 1962). He argued, based on historical analyses of European catch-up with the then leading nation (the UK), that although the technological gap between a frontier country and a laggard represents "a great promise" for the latter - a potential for high growth through imitating frontier technologies - there are also various problems that may prevent backward countries from reaping the potential benefits to the full extent. His favourite example was the German attempt to catch up with Britain more than a century ago. When Britain industrialized, technology was relatively labour intensive and small scale. But in the course of time technology became much more capital and scale intensive, so when Germany entered the scene, the conditions for entry had changed considerably. Because of this, Gerschenkron argued, Germany had to develop new institutional instruments for overcoming these obstacles, above all in the financial sector, "instruments for which there was little or no counterpart in an established industrial country" 
(ibid, p. 7). He held these experiences to be valid also for other technologically lagging countries.

\subsection{Social capability}

Moses Abramovitz, arguing along similar lines as Gerschenkron, also placed emphasis on the potential for catch-up by late-comers which he defined as follows: "This is a potential that reflects these countries' greater opportunity to advance by borrowing and adapting the best practice technology and organization of more productive economies" (Abramovitz, 1994a, p. 87). He suggested that differences in countries' abilities to exploit this potential might to a large extent be explained by differences in "social capability". What he had in mind was not only individual skills (acquired through education) but "collective capabilities" related to what organizations in the private and public sector are capable of doing and how this is supported (or hampered) by broader social and cultural factors. These are some of the aspects of social capability that he emphasized as being particularly important (see Abramovitz (1986, pp. 387-390; 1994a, pp. 34-35; 1994b, p. 88):

- technical competence (level of education),

- experience in the organization and management of large scale enterprises,

- financial institutions and markets capable of mobilizing capital on a large scale,

- honesty and trust,

- the stability of government and its effectiveness in defining (enforcing) rules and supporting economic growth.

The concept "social capability" soon became very popular in applied work. But there have not been many attempts to develop empirical measures reflecting the factors that Abramovitz considered to be important. He pointed out, in later work, that the concept 
continued to be "vaguely" defined (Abramovitz 1994b, p. 24 and 36) and expressed pessimism with respect to the possibilities for adequate measurement. In practice it has often been assumed to be synonymous with educational attainment (Baumol et al., 1989) which, although arguably an important element, is a much more narrow perspective than what Abramovitz had in mind.

\subsection{Technological capability}

The approach of Gerschenkron and Abramovitz was strongly rooted in a specific view of modernity that developed as a result of the rise of the US economy to global economic leadership during the previous century. This perspective, whose most prominent advocate was the economic historian Alfred Chandler (Chandler, 1977), focused on the economics of large, integrated companies and the social, economic and organizational capabilities needed to support and finance them and it was assumed that countries seeking to catch up with the frontier would have to place emphasis on emulating these capabilities (Chandler, 1990).

This widely shared focus was challenged, however, with the downturn of the economies in the Western world and the rise of a new formidable global competitor, Japan, in the 1970s and 1980s. It soon became evident that Japanese companies were successful for reasons that had little or nothing to do with "the American way". Nonaka and Takeuchi (1995), in a seminal study, showed that sustained emphasis on exploration and exploitation of technology, and getting the organizational prerequisites for that right, was a major factor behind the Japanese success stories. They coined the concept "the knowledge-creating company", signalling the change of perspective from "the scale and scope" paradigm of Chandler to a focus on the ability of a firm to innovate. Another popular concept in the applied literature that touches on some of the same issues is "absorptive capacity". Wesley 
Cohen and Daniel Levinthal who suggested the term defined it as "the ability of a firm to recognize the value of new, external information, assimilate it and apply it to commercial ends" (Cohen and Levinthal, 1990, p. 128). To generate such abilities, they argued, sustained investments in technological activities were necessary.

The study of the catch-up of not only Japan, but also a host of other so-called "newly industrializing countries" - NICs - in the 1970s and 1980s was associated with the development of a new perspective on the dynamics of the global economy which put the development of appropriate technological activities (or capabilities) at the core of the analysis (Fagerberg, 1987, 1988; Dosi et al. 1990; for an overview see Fagerberg and Godinho, 2004). One case which received a lot of attention is the rise of Korea from being one of the poorest countries in the world to first world technological powerhouse in just three decades. Linsu Kim who made the authoritative study on the subject suggested the concept "technological capability", which he defined as "the ability to make effective use of technological knowledge in efforts to assimilate, use, adapt and change existing technologies.” (Kim 1997, p. 4). This definition is, as the reader may observe, quite similar to that of "absorptive capacity", and Kim used the two concepts interchangeably. He considered three aspects of it; innovation capability, production capability and investment capability. Thus, the concept includes not only organized $\mathrm{R} \& \mathrm{D}$, which arguably is a small activity in many developing countries, but also capabilities needed to exploit technology commercially.

Hence, recent research sides with Gershenkron in his emphasis on capability-building as a necessary element for "catching up". However, the strong focus on scale and finance that characterizes many early contributions in this area has given way to a more balanced approach that also places emphasis on the need to generate technological capabilities.

\subsection{The national innovation system}


The 1990s also saw the birth of a large body of research aimed at exploring the interrelationships between firm level exploration and exploitation of knowledge and external knowledge providers, many of them public, and the important role of governance and policy in shaping this dynamics. The concept "national innovation system", first used in public by Christoper Freeman in an analysis of Japan (Freeman, 1987), became a popular analytical tool for researchers who wanted to get a firmer grasp of what determined the performance of such interaction (Lundvall, 1992; Nelson, 1993; Edquist, 1997) and organizations such as the OECD, the EU and the UN intensified its efforts to provide relevant statistics with which such performance could be assessed (or "benchmarked"). However, the adoption of the innovation system approach to developing countries is a relatively recent phenomenon and arguably still in its infancy (Viotti, 2002; Muchie et al., 2003; Lundvall et al., 2006).

Moreover, there is currently no agreement in the literature on how innovation systems should be defined and studied empirically. ${ }^{1}$ Edquist (2004, p. 182) argues for example that national systems of innovation include "all important economic, social, political, organizational, institutional, and other factors that influence the development, diffusion, and use of innovations". Trying to put numbers on such broad concepts may be a challenge, as Archibugi and Coco (2005) point out. Still there have been some attempts in that direction. For instance, Furman, Porter and Stern (2002) and Furman and Hayes (2004) have suggested to measure a country's innovation system (or its "innovative capacity" as they put it) through the number of patents that its population generates and find that there are large differences in this respect across countries at similar levels of income. ${ }^{2}$ However, for countries below the technology frontier, and developing countries in particular, most of their innovative activities would get unrecognized by this approach. Patents refer to inventions, not innovations, and are used much more intensively in some industries than others. Moreover, the global novelty 
requirement associated with patents implies that minor innovations/adaptations, which arguably make up the bulk of innovative activity world-wide, will not be counted since these are simply not patentable.

\subsection{New growth theory}

During the 1980s and 1990s neoclassical economists' interest in the possible role of knowledge (technology) for growth and development also increased. An important development was the emergence of the so-called "new growth theory" (Romer, 1986, 1990; Aghion and Howitt, 1992, 1998) according to which differences in economic development across countries should be understood as the outcome of endogenous knowledge accumulation within (largely national) borders. Although some newly created technological knowledge may spill over from one country to another, there are according to this approach sufficient impediments to this process to secure ensure that most benefits accrue to the innovating country. Following this approach long run economic development should be expected to depend on economic incentives to innovation, e.g., strong intellectual property rights (patents) backed by a well-functioning legal system; supply of needed skills (education); access to relevant knowledge sources; availability of finance, and - not the least - the size of the country. In fact, the theory predicts that large countries should be expected to be more innovative, and benefit more from innovation, than small countries. However, according to the theory, small countries may to some extent overcome the disadvantages of scale by practicing free trade and taking a liberal stance towards international capital flows. Hence, following this approach, openness to trade and foreign investment should be considered as essential for countries that wish to catch up (Grossman and Helpman, 1991; Coe and Helpman, 1995). 


\subsection{Research agenda}

Thus there is by now a relatively large literature on the role of capabilities in development, conceptual and applied. However, as should be evident from the discussion, scholars in this area have suggested alternative concepts that are to some extent overlapping and often difficult to operationalize. Among the topics that are in need of clarification are:

1) How should technological capability be defined and measured? In the literature there are at least two approaches, one broad and one narrow. The latter constrains the analysis to (patented) innovations at the global technology frontier. The former, broader approach, attempts to take into account all kinds of innovations; global or local; large or small. As pointed out above the narrow approach effectively excludes from consideration a large part of world-wide innovative activity and this holds in particular for the developing part of the world. Hence from the viewpoint of economic development one might prefer the broader approach. But to what extent is this possible in practice? Can the broader approach be operationalized in a logical and transparent manner and are there reliable data sources for a sufficiently large number of countries that can be used in such an exercise? These are among the questions that we are going to deal with in the next section.

2) Another unresolved issue relates to the relationship between technological capability proper and the broader social, institutional and political framework, what Moses Abramovitz called "social capability". The importance of the latter can hardly be questioned but, again, can it be defined in a way that makes it possible to examine this dimension empirically in a rigorous manner? Abramovitz was as noted above quite pessimistic in this regard. But the availability of indicators has improved in recent years, not the least for "non- 
economic" aspects of development, and we may now be much better placed to make real progress in dealing with this important and challenging issue.

3) Finally there is an aspect to which Abramovitz did not devote much attention but which has figured prominently on the agenda of empirical growth research in recent years, namely how to distinguish between what we can do something about within a reasonable time frame (and which hence might be the object of policy) and factors, that although important for development, should simply be taken as given? Geographical and natural conditions are typical examples of the latter. But it has been argued that also factors related to history, culture, religion, institutions etc. may in fact belong to this category. This is, of course, an important and interesting research topic in itself (albeit not the main focus here). However, what makes it of primary importance in the present context too is that by not taking into account such factors we may wrongly attribute effects to man-made capabilities that in fact are caused by exogenous factors beyond the control of people living today.

\section{In search of a synthetic framework}

The main purpose of this paper is to contribute to an improved (and more transparent) relationship between conceptual and applied work in this area. We start by examining the relationship between concepts and indicators. Based on the preceding discussion, Figure 1 presents an overview of the factors that we expect to be of particular relevance for catch-up, along with possible indicators. 
Figure 1. Capabilities and development - an integrated framework
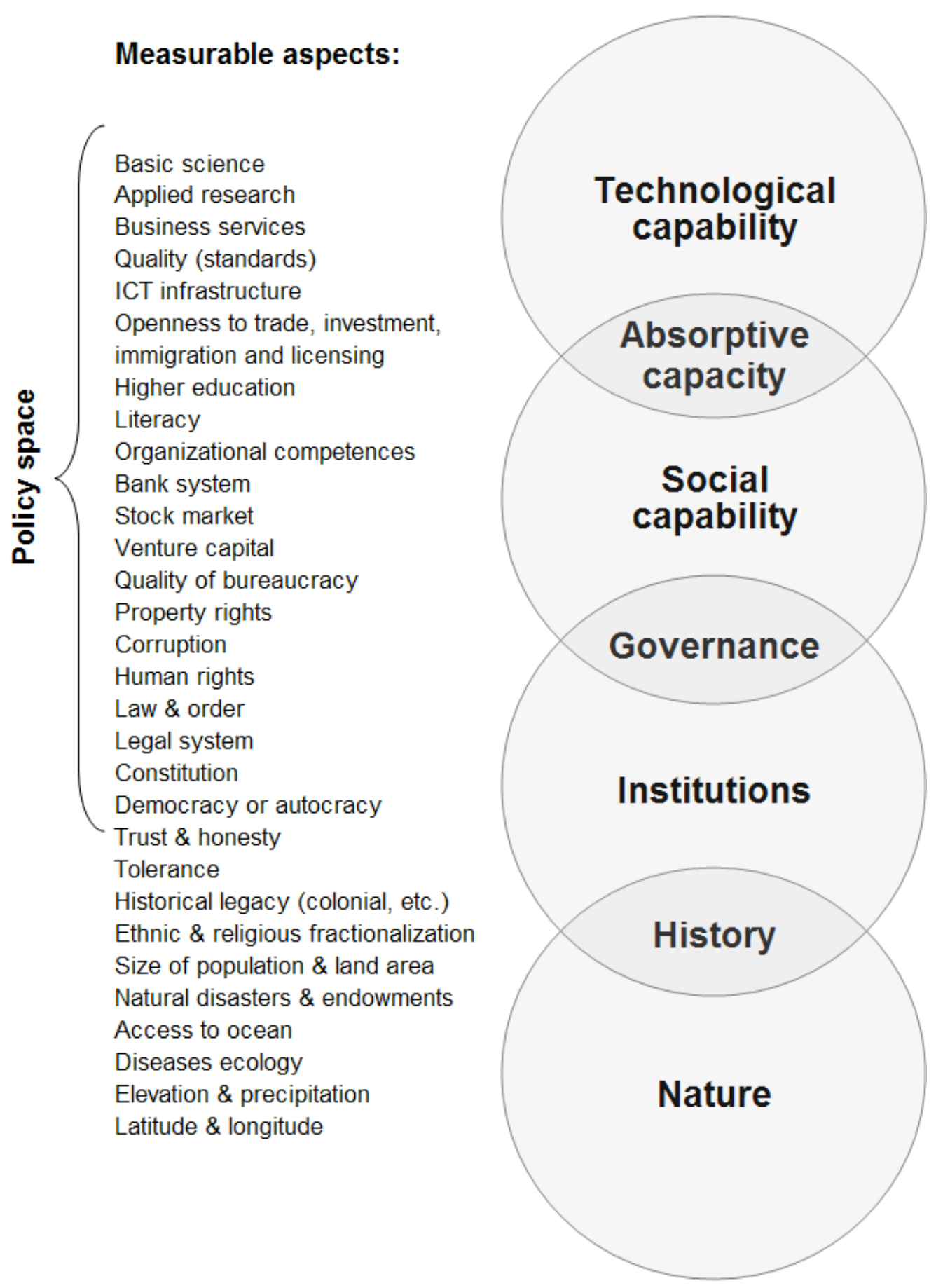

As discussed earlier, the concepts "technological capability" and "absorptive capacity" both refer to the ability to develop and exploit knowledge commercially. At the core of this we find the ability to innovate, what Kim (1997) termed "innovation capability". There are several data sources that capture this dimension. For instance, research and development 
(R\&D) expenditures measure some (but not all) resources that are used for developing new products or processes, while patents count (patentable) inventions coming out of that process. ${ }^{3}$ However, the former data source is not available for many developing countries, which led us not to include it in the analysis. The quality of a country's science base, on which invention and innovation activities to some extent depend, are reflected in articles published in scientific and technical journals. ${ }^{4}$ Patent and article counts are very reliable data sources. However, it should be kept in mind that the propensity to patent or publish varies considerably across scientific fields and sectors and that many innovations are not registered by these means. Basing the analysis of technological capability exclusively on these sources might therefore lead to a biased representation of the evidence.

A well-developed ICT infrastructure is widely acknowledged as a critical factor for the ability to develop and exploit new technology. We include three indicators of ICT diffusion in the economy: personal computers, Internet users and fixed/mobile phone subscribers. However, ICT is equally (or even more) important for another dimension of technological capability emphasized by Kim, namely "production capability”. As an additional indicator of this we also include the adoption of quality standards (ISO 9000). Although ISO certification is mainly procedural in nature, it is increasingly seen as a requirement for firms supplying high quality markets and is therefore likely to reflect a high emphasis on quality in production.

Openness (or interaction) across country borders may serve as an important channel of technology transfer (or spillovers) from abroad. This issue is as mentioned particularly emphasized in work inspired by the "new growth theories". Four channels of technology transfer across country borders have been examined in the literature: trade, foreign direct investment (FDI), migration and licensing (for overviews see Cincera and Van Pottelsberghe, 2001; Keller, 2004). However, due to lack of data we only take into account the two former, 
e.g.; diffusion of technology embodied in (merchandise) imports ${ }^{5}$ and (stock) of inward FDI. To avoid a bias against large economies (that for natural reasons trade/interact relatively more internally) both indicators were measured orthogonal to country size. ${ }^{6}$

An important aspect of "social capability", according to Abramovitz, is the ability to organize and manage large scale enterprises ("organizational competences"). This is, as acknowledged by Abramovitz himself, a hard thing to measure, particularly for a large sample of countries on different levels of development. Although we have scrutinized the available data sources for relevant information, we have not been able to improve upon the existing literature in this respect. What most of the applied literature on the subject has done, following the influential study by Baumol et al. (1989), is to identify "social capability" with education. There is a host of other contributions that also points to the importance of education and/or human capital for growth (Nelson and Phelps, 1966; Barro, 1991; Benhabib and Spiegel, 1994; for an overview see Krueger and Lindahl, 2001). Hence this is obviously an important dimension to take into account. The three indicators taken into account here are the teacher-pupil ratio in primary education and the rates of enrolment in secondary and tertiary education. It would have been desirable to also include numbers of educated engineers and natural scientists but due to data limitations this was not possible.

In addition Abramovitz pointed to the crucial role of country's financial system for mobilizing resources for catching-up, as also emphasized by other recent research (King and Levine, 1993; Levine, 1997; Levine and Zervos, 1998). We capture this aspect by the amount of credit (to the private sector) and by capitalization of companies listed in domestic capital markets. However, these indicators mainly reflect the development of financial markets, while many writers in this area, such as for instance Kim (1997), have focused on firm's own abilities to generate finance for new projects, for which we unfortunately do not have data. Note, also, that Kim (1997) included such aspects of finance (what he called "investment 
capability") in his definition of "technological capability", illustrating once more the partly overlapping nature of some of the most widely used concepts in this area.

The importance of governance and institutions, furnishing economic agents with incentives for creation and diffusion of knowledge, is generally acknowledged in the literature. This holds not only for Abramovitz, who as mentioned previously included several such aspects into his definition of "social capability", but also for writers from other strands. Although such factors often defy "hard" measurement, especially in a broad cross-country comparison, there exist some survey-based measures that may be considered here. ${ }^{7} \mathrm{We}$ include indicators of law and order, independence of courts, protection of property rights, regulation of business, perception of corruption, degree of democracy versus autocracy, checks and balances in the political system, degree of competition for posts in the executive and legislature and the extent of political rights and civil liberties. ${ }^{8}$

Finally, towards the bottom of the graph, we include social characteristics that are the result of historical processes in the distant past, such as language, religion, ethnic divisions, colonial legacy etc. (Acemoglu et al., 2001, 2002; Alesina et al., 2003), and which may be hard or impossible to change within a reasonable time frame through policy interventions. This, obviously, also holds for differences in geography and nature, which has been the focus of many recent empirical studies of differences in growth and development (Masters and MacMillan, 2001; Bloom et al., 2003; Sachs et al., 2004). We do not include such factors in what we call the "policy" (or "capability") space. But as noted above it is important to take such factors into account in the analysis (to avoid biased inferences).

Although measurability is a key issue for the present exercise, data availability proved to be a serious concern as well. Typically, most developed market economies figure prominently among those with good coverage, while developing countries and former socialist economies lack data on many potentially useful indicators. Based on an initial 
screening of data for 175 countries and more than 100 relevant indicators we chose to include 115 countries and 25 indicators into the analysis (for details on definitions and sources see Appendix 1). Still there were a few missing data points for many countries/indicators. Excluding all countries with one or more missing observations would imply to consider only a small group of highly developed countries. Also not taking into account all indicators for which some country lacked data would lead to ignore many of the potentially most interesting explanatory factors. In such cases we therefore chose to estimate the missing observations with the help of information on the other indicators and countries (see Appendix 1 for details on how this was done).

To ensure comparability over time and across countries, all indicators were measured in real units (quantity), deflated (if applicable) with population or GDP and on an increasing scale from low score (weak) to high score (strong). ${ }^{9}$ To limit the influence of shocks occurring in specific years, we express the indicators as three-year averages for the initial period over 1992-1994 and for the final period over 2002-2004. A longer time period would clearly been desirable but that would have implied that many of the data sources taken into account would not been available and/or that most developing countries would have had to be excluded from the analysis. 


\section{Constructing composite variables: factor analysis}

Given the relatively large number of indicators there is obviously a lot of information to exploit in the analysis. One of the key challenges confronting us in this study is how to combine this information into a smaller number of dimensions with a clear-cut economic interpretation. The most widely used approach to construct composite variables is to select relevant indicators and weigh them together using predetermined (usually equal) weights, see Archibugi and Coco, 2005 for an overview. The problem with this is that the choice of weights tends to be quite arbitrary. An alternative approach, pioneered by Adelman and Morris (1965, 1967), uses so-called "factor analysis" (Basilevsky, 1994) to advice on questions like this. This method is based on the very simple idea that indicators referring to the same dimension are likely to be strongly correlated, and that we may use this insight to reduce the complexity of a large data set (consisting of many indicators) into a small number of composite variables, each reflecting a specific dimension of variance in the data.

Factor analysis is carried out in two steps. First the factors (or dimensions) are identified and a solution is found in terms of number of factors to be retained.). Maximum likelihood factor analysis has the advantage that it provides significance tests for the extracted factors and goodness of fit of the model. However, the method requires multivariate normality of the data. If this assumption does not hold, misleading results may occur, as happened in the present case (a so-called Heywood solution). Principal factors estimation, which is more robust to different distributions of the data, was therefore preferred. The so-called Kaiser criterion (eigenvalue above unity) was used to determine the number of factors to be retained. The solution was found to be consistent with a "scree test".

Then, in a second step, the loadings of the various indicators on the retained factors are adjusted through so-called "rotation" to maximize the differences between them (without 
changing the number of factors or the share of the total variance in the data that these jointly explain). Orthogonal rotations, such as "varimax normalized" rotation, have often been used applied work, mainly because these are computationally less demanding than the more complex alternatives. However, orthogonal rotations assume that the underlying factors are (totally) uncorrelated. Although an attractive feature in many respects (not the least in regression analysis) this is a very strong assumption that may be difficult to defend. Arguably, in the real world, there is a good deal of correlation between different social factors, and hence one would like to use a method that allows for that. For this reason we use the more flexible "oblique" rotation which are both more plausible and easier to interpret (see Fabrigar, et al. 1999 for a detailed discussion). However, if the orthogonality assumption holds, oblique and orthogonal rotations will generate very similar solutions.

Outliers in the data set can impact correlations significantly and thus distort factor analysis, which proved to be a problem in the present case. Simply excluding the outliers from the sample may not be the best solution, as we then may lose important evidence. Instead, we use all of the variables in logs. ${ }^{10}$ After the log-transformation of the data set Mahalanobis' distance criterion did not identify any outliers (Mahalanobis, 1936).

A characteristic of the factoring procedure is that the variables are standardized by deducting the mean and dividing by the standard deviation. We used the mean and standard deviation of pooled data (from the initial and the final period), which means that the change of a composite variable over time reflects both changes in each country's position (relative to other countries) and changes in the importance of the underlying indicators (over time) in the composite. In this way we take into account as much information as possible.

In Table 1 we present results of the factor analysis on the pooled data for the 115 countries covered by the analysis (both the initial and final period and therefore 230 observations). As mentioned we used the method of principal component factors (Stata 9.2) to 
extract the factors and the oblique "oblimin" procedure to rotate the solution. The analysis led to the selection of four principal factors jointly explaining $74 \%$ of the total variance. The table presents loadings of the variables on the retained factors after the rotation (so-called pattern matrix). Factor loadings are the correlation coefficients between the variables (rows) and factors (columns) and provide the basis for interpreting the different factors. ${ }^{11}$

Table 1. Results of factors analysis

\begin{tabular}{lrrrr}
\hline & $\begin{array}{c}\text { Innova- } \\
\text { tion } \\
\text { system }\end{array}$ & $\begin{array}{c}\text { Gover- } \\
\text { nance }\end{array}$ & $\begin{array}{c}\text { Political } \\
\text { system }\end{array}$ & Openness \\
\hline USPTO patents (per capita) & 0.63 & 0.33 & 0.14 & -0.08 \\
Science \& engineering articles (per capita) & 0.63 & 0.42 & 0.06 & -0.12 \\
ISO 9000 certifications (per capita) & 0.81 & 0.04 & 0.00 & 0.26 \\
Fixed line and mobile phone subscribers (per capita) & 0.94 & 0.00 & 0.03 & 0.06 \\
Internet users (per capita) & 0.81 & -0.18 & 0.09 & 0.31 \\
Personal computers (per capita) & 0.79 & 0.17 & 0.00 & 0.17 \\
Primary school teacher-pupil ratio & 0.82 & 0.17 & -0.10 & -0.18 \\
Secondary school enrolment (\% gross) & 0.92 & -0.07 & 0.03 & -0.13 \\
Tertiary school enrolment (\% gross) & 0.95 & -0.09 & 0.08 & -0.18 \\
Domestic credit to private sector (\% of GDP) & 0.47 & 0.44 & 0.00 & 0.09 \\
Market capitalization of listed companies (\% of GDP) & 0.46 & 0.32 & 0.05 & 0.21 \\
Merchandise imports (\% of GDP) & -0.11 & 0.04 & -0.12 & 0.77 \\
Foreign direct investment inward stock (\% of GDP) & 0.05 & -0.01 & 0.10 & 0.85 \\
Impartial courts & -0.09 & 0.88 & -0.04 & -0.07 \\
Law and order & 0.21 & 0.59 & -0.07 & 0.00 \\
Property rights & 0.00 & 0.87 & 0.16 & 0.01 \\
Regulation & 0.11 & 0.71 & 0.04 & 0.00 \\
Informal Market (corruption) & 0.27 & 0.67 & -0.03 & 0.21 \\
Index of democracy and autocracy & -0.04 & -0.03 & 0.96 & -0.03 \\
Political constraint & 0.09 & 0.02 & 0.80 & -0.03 \\
Legislative index of political competitiveness & -0.02 & -0.20 & 0.84 & 0.00 \\
Executive index of political competitiveness & 0.08 & -0.23 & 0.84 & 0.07 \\
Political rights & -0.01 & 0.22 & 0.89 & -0.02 \\
Civil liberties & 0.01 & 0.27 & 0.82 & 0.04 \\
\hline
\end{tabular}

Note: Four factors with eigenvalue $>1$ were detected, which explain $74.0 \%$ of total variance; extraction method: principal components factors; rotation: oblimin oblique. Number of observations $=230$ (pooled data for 115 countries in the initial and final period).

Source: See Appendix 1.

The first factor loads highly on several indicators associated with "technological capability" and "absorptive capacity" such as patenting, scientific publications, ICT 
infrastructure, ISO 9000 certifications and access to finance ${ }^{12}$ However, it also correlates highly with education, so it cuts across the established distinction between "technological" and "social" capabilities. We suggest interpreting it as a synthetic measure of capabilities (or "factors") influencing the "development, diffusion and use of innovations" to use Edquist (2004)'s terminology. Hence, we label this factor “innovation system”, recognizing, however, that this notion in other contexts is often used for institutional and organisational structures (which can be seen as the ultimate sources for the type of data that we are able to take into account here).

Figure 2 plots the factor score on the innovation system against GDP per capita (as a measure of the level of economic development). There is very close correlation between the two. To the extent that there are deviations from the regression line this primarily comes from a group of resource rich economies (OPEC countries for instance), having slightly higher GDP per capita levels than the quality of their innovation systems would indicate, and some of the former centrally-planned economies for which it is the other way around.

It is interesting to note that the broad "innovation system" variable developed here differs in important respects from the more narrowly defined "innovative capacity" variable suggested by Furman et al. (2002) and Furman and Hayes (2004). While, according to their calculations, large economies such as the US, Japan and Germany are among the leaders, the front-runners in our case are all small countries, at least in terms of population (Australia, Sweden Denmark and Norway). This difference is suggestive. Maybe the success of the latter countries, which are among the richest in the world, has to do with particularly well developed abilities in exploiting knowledge, factors that are important for the "innovation system" measure developed here but largely ignored by Furman and associates. 
Figure 2. GDP per capita and innovation system (average level over 2002-2004)

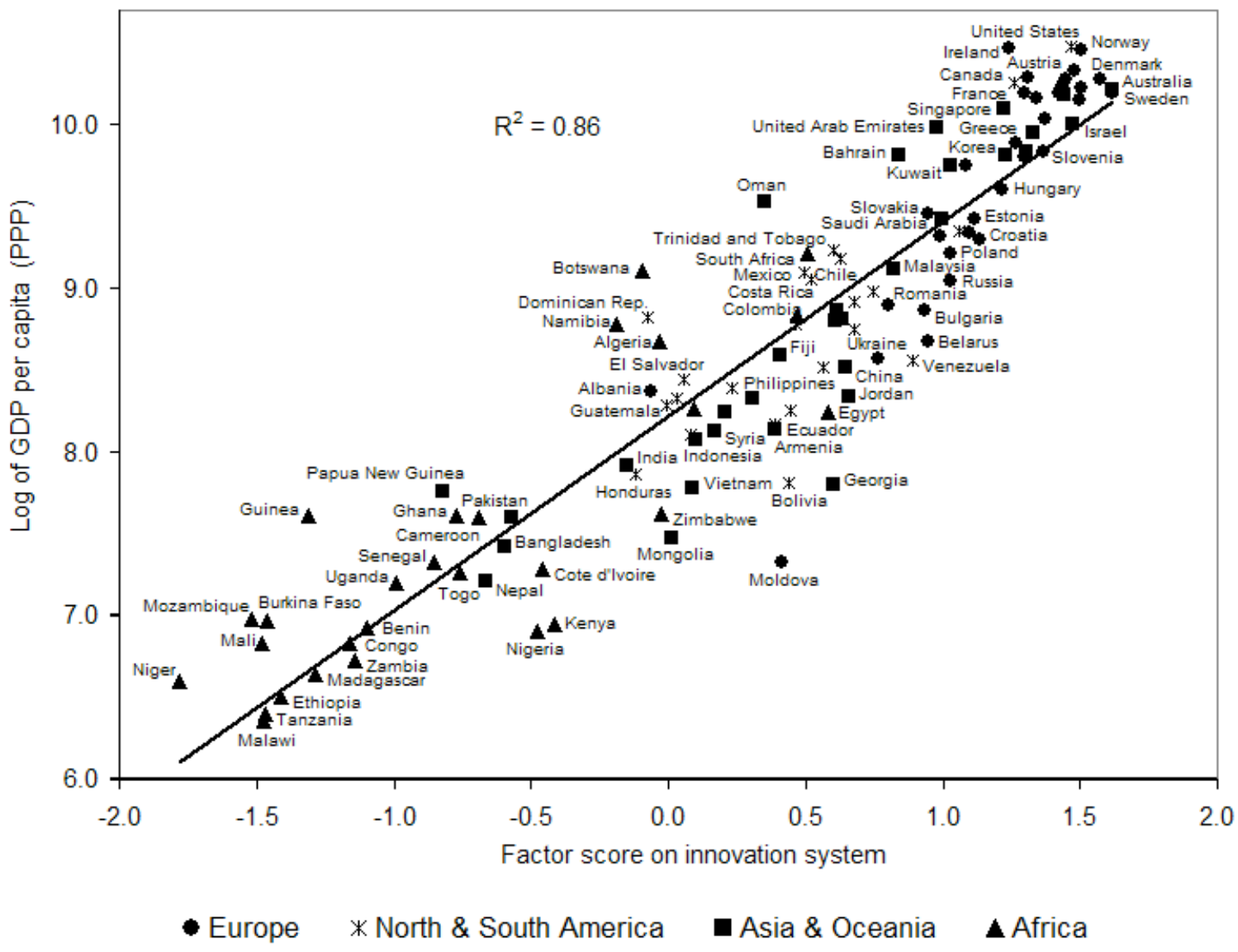

Note: For definition of the innovation system variable see Table 1.

Source: See Appendix 1.

The second factor loads high on various aspects reflecting the quality of "governance", such as adherence to property rights, a well-functioning judicial system, little corruption and a favourable environment for business. As in the previous case this factor score correlates positively with the level of economic development (and significantly so). However, as is evident from Figure 3, the relationship is not as strong as in the case of the innovation system. The main reason for this is that there is a group of countries, mainly of African origin, that deviates from the main pattern by being much poorer than the quality of governance should indicate. 
Figure 3. GDP per capita and governance (average level over 2002-2004)

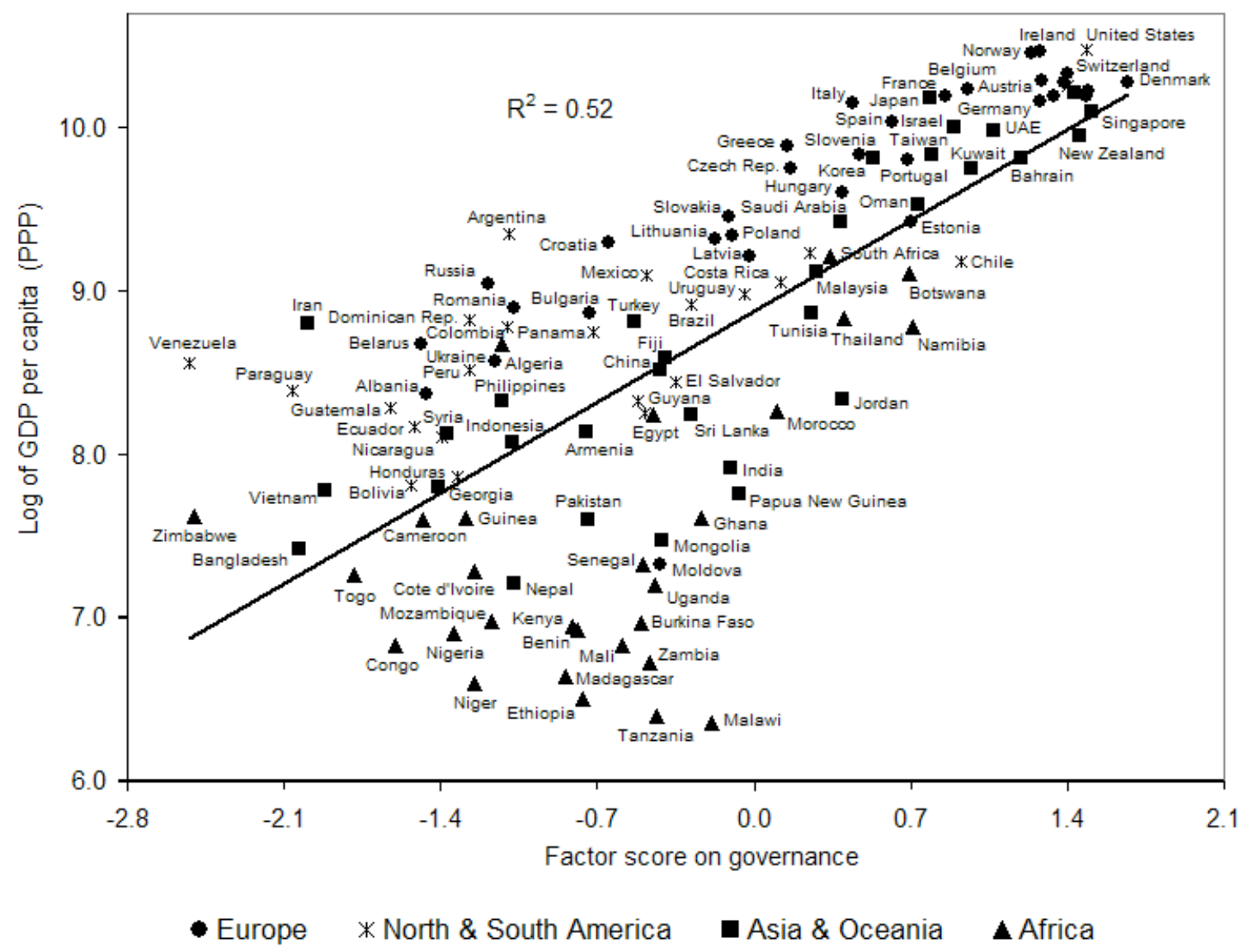

Note: For definition of the governance variable see Table 1.

Source: See Appendix 1.

The third factor, in contrast, loads particularly high on indicators reflecting the character of the "political system" (such as the "rules of the game" given by the constitution). In short, countries with political systems that are close to those of the Western world, rank high on this dimension, while countries with systems that differ from Western democratic ideals, get a low mark. In contrast to the innovation system and governance variables, however, the character of the political system is not closely correlated with levels of development. In fact, Figure 4 reveals that some countries with distinctly authoritarian regimes do rather well economically. However, most countries cluster to the right in the figure indicating a "Western" type political system irrespective of their level of economic development. 
Figure 4. GDP per capita and political system (average level over 2002-2004)

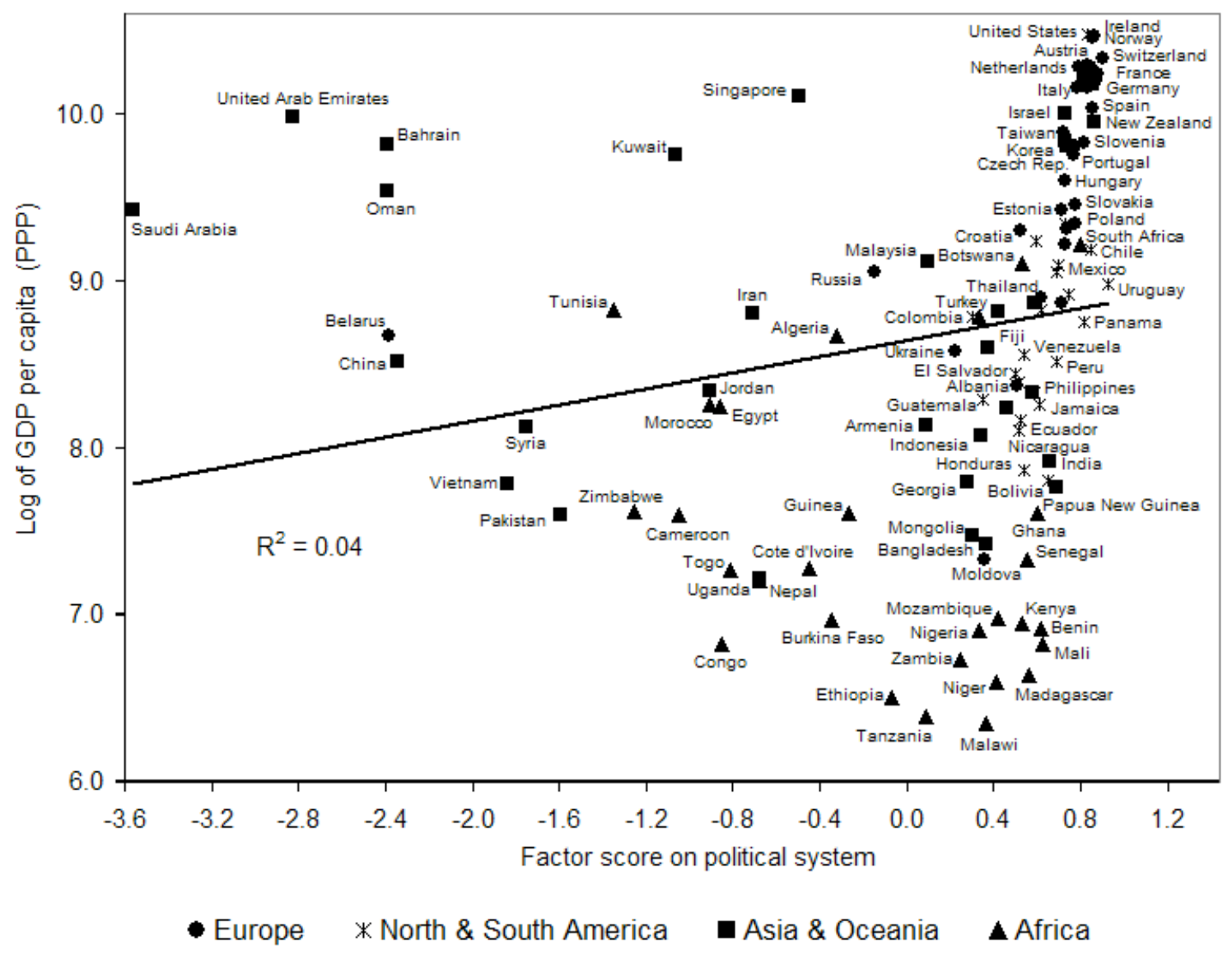

Note: For definition of the political system variable see Table 1.

Source: See Appendix 1.

Finally, there is a fourth factor which may be labelled "openness" as it shows high correlation with imports and inward FDI. As noted this is a factor that is deemed especially important by followers of the "new growth theory". However, Figure 5 shows that the composite variable based on this factor does not correlate with economic development. 
Figure 5. GDP per capita and openness (average level over 2002-2004)

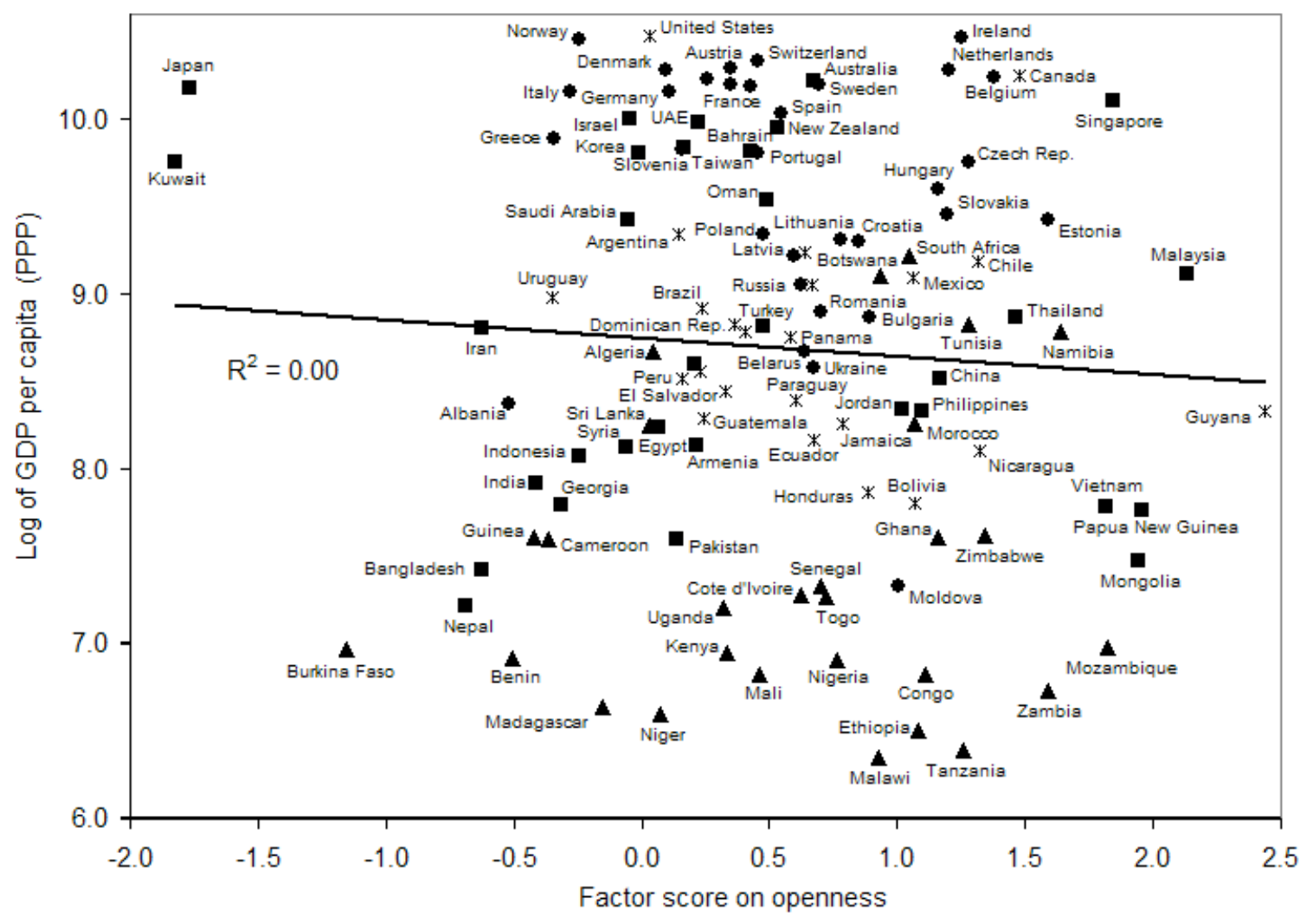

- Europe $\quad *$ North \& South America

Asia \& Oceania

Africa

Note: For definition of the openness variable see Table 1.

Source: See Appendix 1.

Although most indicators load highly on one factor only there are a few exceptions worth noting. For instance, the indicators of financial development load moderately on both innovation system and governance. A well functioning financial system is obviously important for innovation, but it is arguably also intimately related to good governance. Moreover, scientific articles and patenting load highly on the innovation system and (moderately) on governance. Thus, the results indicate that although the quality of the innovation system and that of governance represent different aspects of reality (and it is possible to distinguish between them) there is also a connection between the two. Furthermore, the spread of internet loads highly on the innovation system and moderately on openness. The former clearly concords with our hypotheses but the latter makes sense too. 
Arguably, openness (in an economic sense) should not only be about flows of goods and money across borders but also about flows of ideas for which internet access comes in very handy.

\section{Capabilities and development}

Simple correlations may mask more complex relationships, so in the next step we carry out a multivariate regression of the relationship between the four capabilities previously identified and the level of economic development as reflected by GDP per capita. To avoid simultaneity bias in the estimates we use data from the initial period (average 1992-1994) for the four capabilities and the final period (average 2002-2004) for GDP per capita.

As customary in the literature we include, in addition to the capabilities mentioned above, a battery of indicators reflecting differences in geography, nature and history. After a screening of the recent literature on the role of such exogenous factors for growth (Acemoglu et al., 2002; Alesina et al., 2003; Bloom at al., 2003; Fearon, 2003; Gallup et al., 1999; Masters and McMillan, 2003; Sachs and Warner, 2001; Sachs et al., 2004), the following thirteen variables were selected: longitude of country centroid, latitude of country centroid, $\log$ of surface area, access to ocean, land in desert ecozone, land in tropical ecozone, log of population density, ethnic fractionalization, religion fractionalization, malaria fatal risk, log of oil deposits per capita, log of the number of people killed in natural disasters per capita and $\log$ of years since national independence (see Appendix 1 for details).

Besides an ordinary least squares estimate, we test for the robustness of the results with respect to the composition of the sample by re-estimating this relationship with a robust

regression technique, iteratively reweighted least squares. ${ }^{13}$ To identify the specification with 
the best statistical properties we use a (backward) stepwise regression. ${ }^{14}$ We also provide separate results for samples that only include high and medium income countries.

Table 2 presents the results from the regression analysis. Note that so-called beta coefficients are reported, which allows for direct comparisons of parameter values (see Wooldridge, 2003, pp. 114-115). The main result is that irrespective of econometric method the development of the innovation system and the quality of governance are positively and significantly associated with economic development. For the two remaining capabilities there is no significant relationship.

The introduction of indicators reflecting differences in nature, geography and history led to a slight increase in the explanatory power of the model and a small decrease in the correlation between GDP per capita and the development of the innovation system. Hence, these results confirm that such differences do matter for economic development. Moreover, the results indicate that one important reason for this may be that differences in nature, geography and history influence the ability of a country to develop a well-functioning innovation system. The results are robust to changes in the composition of the sample except that the effect of governance nearly doubled when the least developed countries were excluded. 


\begin{tabular}{lccccc}
\hline & $(1)$ & $(2)$ & $(3)$ & $(4)$ & $(5)$ \\
\hline Estimation method & OLS & $\begin{array}{c}\text { Iteratively } \\
\text { re- } \\
\text { weighted } \\
\text { least } \\
\text { squares }\end{array}$ & $\begin{array}{c}\text { Stepwise } \\
\text { regression }\end{array}$ & $\begin{array}{c}\text { Stepwise } \\
\text { regression } \\
\text { excl. the } \\
\text { poorest } \\
\text { quartile }\end{array}$ & $\begin{array}{c}\text { Stepwise } \\
\text { regression } \\
\text { excl. the } \\
\text { poorest } \\
\text { half }\end{array}$ \\
\hline Constant & & &. .02 &.. &.. \\
Innovation system &.. & 0.02 &.. &.. &.. \\
Governance &.. & $(0.78)$ &.. & $0.76^{* * *}$ \\
& $(18.14)$ & $(19.73)$ & $(14.02)$ & $(9.83)$ & $(11.00)$ \\
Political system & $0.16^{* * * *}$ & $0.13^{* * *}$ & $0.18^{* * * *}$ & $0.30^{* * *}$ & $0.28^{* * *}$ \\
Openness & $(3.35)$ & $(3.08)$ & $(3.93)$ & $(4.91)$ & $(4.48)$ \\
Geography, nature and history & -0.04 & -0.04 &.. &.. &.. \\
\hline F & $(1.08)$ & $(1.31)$ &.. &.. &.. \\
$\mathrm{R}^{2}$ & 0.04 & 0.04 &.. &.. &.. \\
Observations & $(1.07)$ & $(1.25)$ &.. &.. & Yes \\
\hline
\end{tabular}

Note: Dependent variable is log of average GDP per capita over 2002-2004 (PPP, constant 2000 USD). The independent variables of capabilities (factor scores) are their lagged levels from the period 1992-1994. Absolute value of robust t-statistics in brackets; *,**, *** denote significance at the 10,5 and 1 percent levels. Standardized variables used in the estimates (beta coefficients reported).

Can the implications from the above analysis be sustained in a dynamic framework? Many contributions to the empirical literature on cross-country differences in growth performance, despite theoretical differences, share a common empirical framework. So-called Barro-regressions (Barro, 1991) consist of regressing economic growth against initial GDP per capita and a number of other factors that may be deemed relevant. In this framework the GDP per capita variable measures the potential for catch-up (or convergence), while the other variables represent factors that are assumed to "condition" the ability to exploit this potential. ${ }^{15}$ As the conditional factors we include the measures of capabilities developed in this paper and the exogenous variables reflecting differences in geography, nature and history.

The popularity of Barro-regressions in applied work probably owes much to the fact that it is consistent with different theoretical perspectives. As shown by Barro and Sala-i- 
Martin (2003, p. 274-5), the inclusion of the GDP per capita variable may be consistent both with Solow's traditional neoclassical growth model (in which case the level of GDP per capita is assumed to reflect the capital intensity of the economy) and a Schumpeterian perspective (with a low GDP per capita indicating a high potential for diffusion). Still different theoretical perspectives may lead to different conclusions with respect to which conditional factors to include. For instance, until recently it was common to assume away "level-effects" in analyses of economic growth. With the advent of "new growth theory" this changed because, according to this approach, a higher level of, say, knowledge may induce higher growth indefinitely. But level effects may also result from temporary shocks, causing variables to deviate from their steady-state values.

Table 3 presents the results. In the first model we regressed the potential for catch-up (log of initial GDP per capita) and the changes in the capabilities on growth of GDP per capita. Upgrading of the innovation system and the quality of governance appear to be highly significant and positive predictors, while the changes in the political system and openness were found to be uncorrelated with growth. However, the model predicts poorly.

In the second model we add the initial levels of the capabilities along with their changes as possible "conditional factors". Both the level and change of the quality of the innovation system and that of governance were shown to be positive and significant predictors, while as before the two remaining capabilities were found not to matter much. Moreover, the GDP per capita came out significant and with the expected (negative) sign. Also the explanatory power of the model increased significantly. In the third model we applied, as before, a robust regression technique (iteratively reweighted least squares) to test for the impact of outliers. Not much changed with the exception that we now found modest support for positive effects of changes (but not levels) in the degree of openness and the character of the political system. 


\begin{tabular}{|c|c|c|c|c|c|c|}
\hline & $(1)$ & (2) & (3) & $(4)$ & $(5)$ & $(6)$ \\
\hline Model & $\begin{array}{l}\text { Basic } \\
\text { model }\end{array}$ & $\begin{array}{l}\text { Initial } \\
\text { levels }\end{array}$ & $\begin{array}{c}\text { Iteratively } \\
\text { re- } \\
\text { weighted } \\
\text { least } \\
\text { squares }\end{array}$ & $\begin{array}{l}\text { Stepwise } \\
\text { regression }\end{array}$ & $\begin{array}{l}\text { Stepwise } \\
\text { regression } \\
\text { excl. the } \\
\text { poorest } \\
\text { quartile }\end{array}$ & $\begin{array}{l}\text { Stepwise } \\
\text { regression } \\
\text { excl. the } \\
\text { poorest } \\
\text { half }\end{array}$ \\
\hline \multirow[t]{2}{*}{ Constant } & .. & .. & -0.01 & .. & .. & .. \\
\hline & .. & .. & $(0.20)$ & .. & .. & .. \\
\hline Log of the initial GDP per capita & $\begin{array}{l}0.18^{* *} \\
(2.19)\end{array}$ & $\begin{array}{l}-0.76^{* *} \\
(2.16)\end{array}$ & $\begin{array}{l}-0.76 * * * \\
(3.23)\end{array}$ & $\begin{array}{l}-0.51 * * * \\
(2.93)\end{array}$ & $\begin{array}{l}-0.74 * * * \\
(2.80)\end{array}$ & $\begin{array}{l}-0.89 * * * \\
(3.39)\end{array}$ \\
\hline Innovation system & $\begin{array}{l}. . \\
. .\end{array}$ & $\begin{array}{l}0.74 * * \\
(2.28)\end{array}$ & $\begin{array}{l}0.71 * * * \\
(3.17)\end{array}$ & $\begin{array}{l}. . \\
. .\end{array}$ & $\begin{array}{c}0.43^{*} \\
(1.69)\end{array}$ & $\begin{array}{l}0.56^{* *} \\
(2.07)\end{array}$ \\
\hline Governance & .. & $\begin{array}{l}0.39 * * * \\
(2.68)\end{array}$ & $\begin{array}{l}0.44^{* * * *} \\
(3.80)\end{array}$ & $\begin{array}{l}0.36^{* * *} \\
(2.45)\end{array}$ & $\begin{array}{l}0.46^{* *} \\
(2.50)\end{array}$ & $\begin{array}{l}0.43^{* * *} \\
(2.34)\end{array}$ \\
\hline Political system & $\begin{array}{l}. . \\
. .\end{array}$ & $\begin{array}{c}0.07 \\
(0.57)\end{array}$ & $\begin{array}{c}0.06 \\
(0.65)\end{array}$ & $\begin{array}{l}-0.21 * \\
(1.94)\end{array}$ & $\begin{array}{l}-0.41 * * * \\
(2.94)\end{array}$ & $\begin{array}{l}0.34 * * * \\
(2.71)\end{array}$ \\
\hline Openness & $\begin{array}{l}. . \\
. .\end{array}$ & $\begin{array}{c}0.07 \\
(0.64)\end{array}$ & $\begin{array}{c}0.04 \\
(0.45)\end{array}$ & $\begin{array}{l}0.18 * * \\
(2.15)\end{array}$ & $\begin{array}{c}0.17 * \\
(1.79)\end{array}$ & $\begin{array}{l}0.37 * * * \\
(3.12)\end{array}$ \\
\hline$\Delta$ innovation system & $\begin{array}{l}0.31 * * * \\
(3.24)\end{array}$ & $\begin{array}{l}0.48 * * * \\
(4.67)\end{array}$ & $\begin{array}{l}0.49^{* * * *} \\
(5.77)\end{array}$ & $\begin{array}{l}0.27 * * * \\
(3.20)\end{array}$ & $\begin{array}{l}0.33 * * \\
(2.45)\end{array}$ & $\begin{array}{l}0.30^{* *} \\
(2.55)\end{array}$ \\
\hline$\Delta$ governance & $\begin{array}{l}0.36^{* * * *} \\
(3.80)\end{array}$ & $\begin{array}{l}0.38 * * * \\
(3.87)\end{array}$ & $\begin{array}{l}0.47 * * * \\
(6.70)\end{array}$ & $\begin{array}{l}0.34 * * * \\
(3.14)\end{array}$ & $\begin{array}{l}0.48 * * * \\
(4.70)\end{array}$ & $\begin{array}{l}. . \\
. .\end{array}$ \\
\hline$\Delta$ political system & $\begin{array}{c}0.10 \\
(1.43)\end{array}$ & $\begin{array}{c}0.12 \\
(1.32)\end{array}$ & $\begin{array}{c}0.15^{*} \\
(1.98)\end{array}$ & $\begin{array}{l}. . \\
. .\end{array}$ & $\begin{array}{l}. . \\
. .\end{array}$ & $\begin{array}{l}0.24 * * \\
(2.08)\end{array}$ \\
\hline$\Delta$ openness & $\begin{array}{c}0.03 \\
(0.21)\end{array}$ & $\begin{array}{c}0.03 \\
(0.20)\end{array}$ & $\begin{array}{l}0.20 * * \\
(2.16)\end{array}$ & $\begin{array}{l}. . \\
. .\end{array}$ & $\begin{array}{l}. . \\
. .\end{array}$ & $\begin{array}{l}. . \\
. .\end{array}$ \\
\hline Geography, nature and history & & & .. & Yes & Yes & Yes \\
\hline $\mathrm{F}$ & 4.70 & 4.20 & 10.51 & 6.80 & 7.60 & 27.74 \\
\hline $\mathrm{R}^{2}$ & 0.19 & 0.30 &. & 0.43 & 0.52 & 0.73 \\
\hline Observations & 115 & 115 & 115 & 115 & 86 & 57 \\
\hline
\end{tabular}

Note: Dependent variable is annual growth of GDP per capita (PPP, constant 2000 USD) over 1992-2004. Absolute value of robust t-statistics in brackets; *, **, *** denote significance at the 10, 5 and 1 percent levels. Standardized variables used in the estimates (beta coefficients reported).

In the fourth model we included the thirteen exogenous variables previously introduced, reflecting differences in geography, nature and history. A (backward) stepwise regression procedure was used to identify the model with the best statistical properties. A healthy increase in the explanatory power of the model was recorded, confirming that such exogenous factors do indeed matter for development. However, with these external factors included the estimated impact of the level of the innovation system is not significant. These results lend further support to the previous finding that the factors related to geography, nature 
and history hamper the development of a well-working innovation system. As in the previous case there is some support for an impact of openness and political system on growth (although for the levels this time). But contrary to widespread expectations a western type political system appears to have, if anything, a negative impact on growth.

Since the previous exercise suggested that the results for the openness and political system variables may be sensitive to the composition of the sample, we include in the fifth and sixth columns a test for the robustness of the results to the removal of the poorest countries (first the poorest quartile and then the poorest half). The most striking result is that the political system (degree of westernization) has a diametrically opposite effect in poor and rich economies. A significantly negative effect turns to a significantly positive impact when only the richest half is included. Also openness seems to matter more for the richer economies (although there is some evidence of a positive impact, though small, for the larger sample as well). Moreover, the explanatory power of the model increases with development. One possible explanation is that there is more diversity among the poorer economies in how their economies work. But it may also have to do with measurement problems, which arguably may be expected to be more severe in poor countries.

The possibility of a endogeneity bias in the estimates, due to a possible feedback from economic growth on capability changes, was investigated by the Hausman (or Durbin-WuHausman) procedure. This test is performed by first regressing each potentially endogenous explanatory variable on all exogenous variables (including the instruments), and then, in a second step, the residuals from these regressions are added as additional variables in a new regression of the original model (for further details see Wooldridge, 2002, pp. 118-122). ${ }^{16}$ If some of the residuals come out as significant in this latter regression, we accept endogeneity of the variable and the model should be estimated by two-stages least squares in order to 
obtain consistent results. However, in the present case the test failed to detect evidence of endogeneity bias.

\section{Concluding remarks}

In recent years the quality and availability of data on different aspects of development have improved, and this might give researchers in this area an opportunity for investigating the reasons behind the large differences in economic performance in more depth. Based on a review of the existing theoretical and empirical literature and an extensive search for available data sources this paper has, with the help of factor analysis, identified a set of "capabilities" which - following (one or more of) the theoretical perspectives that have been advanced in this area - should be assumed to be of critical importance for catch up:

The development of the "innovation system"

The quality of "governance"

The character of the "political system"

The degree "openness" to technology/knowledge from abroad

The empirical analysis suggests that a well developed innovation system is essential for countries that wish to succeed in catch up. There is a strong, significant and robust statistical relationship between (level and change of) GDP per capita on the one hand, and (level and change of) the innovation system on the other. Historical and descriptive evidence also suggest that countries that have succeeded in catch up have given a high priority to this dimension of development (Wade, 1990; Nelson, 1993; Kim, 1997).

Although a well functioning innovation system emerges from the analysis as an essential prerequisite for development, it is not sufficient. Good governance is also critical for the ability to realize the desired economic results. Sometimes it is asserted that this is mainly a question of successfully "westernising" the political system, e.g., adapting to the 
institutional arrangements that have proved to be successful in the United States and other western democracies . This study, confirming previous research by Barro (1996) and Glaeser et al. (2004), finds the support for these assertions to be rather weak. On the contrary we show that it is among the richer economies that a political system of the Western type is shown to be conducive to growth. For the poor countries it is, if anything, the other way around. In fact, among the countries that over the years have succeeded in catching up there are several examples of countries with institutional arrangements that differ a lot from western ideals (such as the recent performance of China and Vietnam, the Asian Tigers before the 1990s or pre-world-war-two Japan).

Another result from the study is that there is little support for the argument that differences in openness matter much for development. This holds even when, as in the present case, country size is controlled for. The result is consistent with previous research by Rodrik et al. (2004). It also concords with previous findings by Xu (2000) and Dunning and Narula, (2000) that poor countries due to lack of absorptive capacity are much less likely than other countries to benefit from foreign direct investments. Although a positive correlation between openness and growth is reported in some cases, the degree of correlation is low, and sensitive to changes in the composition of the sample. Again, it is among the richer economies that openness seems to matter most for growth.

In general the picture that emerges from this study is one of a global knowledge-based economy with strong elements of endogenous growth. Countries that succeed in developing and sustaining strong innovation capabilities and well-functioning systems of governance do well economically while those that fail tend to fall behind. However, many countries in the poorer part of the globe find it hard to develop the capabilities, a well functioning innovation system in particular, necessary for joining this virtuous dynamics. An innovation system is something that is built incrementally over many years. The results reported here suggest that 
many present-day poor countries have been hampered in developing an innovation system by

a combination of unfavourable factors related to geography, nature and history and that such

factors continue to affect the economies of these countries negatively. This arguably provides

an additional argument for development aid, since some countries are much worse placed than

others for reasons that are beyond the control of people living today (or their politicians).

\footnotetext{
${ }^{1}$ Some researchers in this area emphasise a need for developing a common methodology, based on the functions and activities of the system, to guide empirical work (Liu and White, 2001; Johnson and Jacobsson, 2003 and Edquist, 2004), while others advocate the advantage of keeping the approach open and flexible (Lundvall 2003).

${ }^{2}$ Furman and associates also drew inspiration from the so-called "new growth theories", to be discussed below.

${ }^{3}$ We use only patents granted by the United States Patent and Trademark Office (USPTO) to assure consistency in terms of criteria for novelty, originality, etc.

4 There can be an upward language/regional bias for English-speaking nations and/or countries with a close links to the United States. No attempt was made to correct for these possible biases.

${ }^{5}$ Knowledge (technology) may also be acquired from foreign customers through exports of goods and services, and some catching-up economies have historically placed strong emphasis on this aspect. However, exports and imports as shares of GDP are likely to be highly correlated, so it was not possible to take into account this aspect separately here.

${ }^{6}$ The variables were regressed against (the log of) land area and the residuals from these regressions were then used in the analysis.

7 Among the aspects included in Figure 1 (and emphasized by Abramovitz), and for which survey-based indicators do exist but with too low coverage to allow inclusion here, are "tolerance" and "honesty and trust". In the more recent literature such aspects are often seen as related to "social capital", e.g. the ability of a population to engage in socially beneficial, cooperative activities, (see Woolcock and Narayan, 2000 for an overview).

${ }^{8}$ Note that because of limited or no time-series, we cannot use the indicators developed by Djankov et al. (2002), Botero et al. (2004) and the World Bank's "Investment Climate Survey" project. For the same reasons we cannot use the indicators on constitutional rules and judicial independence proposed by La Porta et al (2004) and on legal procedures suggested by Djankov et al. (2003). Nor were we able to use the composite "governance matters" indicators developed by the World Bank because these, as explained by Kaufmann et al. (2003, p. 31), by construction eliminate the time trend in the data (such as, for instance, a general trend towards more or less democratic government which clearly would be of interest here). However, the sources for many of the "governance matters" indicators are often the same as those utilized here (see appendix 1), so much of the information is taken into account in this study as well.

${ }^{9}$ If necessary we reversed scale of the indicators to have all of them in an increasing order, e.g. we use teacher-pupil ratio instead of the opposite.

${ }^{10}$ Some variables containing zeros or negative scale had to be rescaled to positive values. We used a simple rule by adding the minimum observed value in the sample, which delivers the transformation, to all of the observations in the sample.

${ }^{11}$ It should be noted that in the case of oblique rotations one needs to examine both the pattern and the structure matrix. Coefficients in the pattern matrix represent the unique contributions of the variables, while the structure matrix (as in orthogonal rotations) contains both the unique and the common contributions. For the sake of space we report the pattern matrix only, because the interpretations of the two are not qualitatively different.

${ }^{12}$ It also correlates strongly with R\&D. For the 75 countries for which R\&D data were available the correlation coefficient between R\&D as a percentage of GDP (in logs) and the "innovation system" variable was 0.65.

${ }^{13}$ Iteratively reweighted least squares is a robust regression technique, which assigns a weight to each observation, with lower weights given to outliers (rreg command in Stata 9.2).

${ }^{14}$ The aim of the stepwise procedure (stepwise reg command in Stata 9.2) is to eliminate (insignificant) variables that do not contribute to the explanatory power of the model (given a chosen significance level). At each step the stepwise method also attempts to reintroduce already eliminated variables to control for a possibility that some of them might become significant later on. We specified the threshold for removal at $20 \%$ level of significance and the level for reintroducing a variable at $15 \%$.
} 
15 The first to introduce this technique to the study of growth and development was probably John Cornwall (1976). Cornwall used GDP per capita to measure the gap in technology between frontier and the late-comer countries. The higher this gap, he pointed out, the higher the potential for high growth in late-comer countries through successful imitation of superior technology developed elsewhere. However, in his view, to exploit this gap countries needed to do additional investments (and that is where the "conditional" aspect comes in). See Fagerberg (1994) for an extended discussion.

${ }^{16}$ The following exogenous variables of geography, history and nature that were excluded from the "best" model by the stepwise regression were used as instruments: latitude of country centroid, ethnic fractionalization, malaria fatal risk, land in desert ecozone and log of the number of people killed in natural disasters per capita (see Appendix 1 for details). All of them proved to be valid instruments according to the criteria of the method, e.g., they were significantly correlated to at least one of the potentially endogenous variables. 


\section{References}

Abramovitz, M., 1986. Catching Up, Forging Ahead, and Falling Behind. Journal of Economic History 46, 386406.

Abramovitz, M., 1994a. The Origins of the Post-war Catch-Up and Convergence Boom, in Fagerberg, J., Verspagen, B., von Tunzelman, N. (Eds.), The Dynamics of Technology, Trade and Growth. Edward Elgar, Aldershot, pp. 21-52.

Abramovitz, M., 1994b. Catch-up and Convergence in the Postwar Growth Boom and After, in Baumol, W. J., Nelson, R. R., Wolf, E. N. (Eds.), Convergence of Productivity - Crossnational studies and historical evidence. Oxford, Oxford University Press, pp. 86-125.

Acemoglu, D., Johnson, S., Robinson, A., 2001. The Colonial Origins of Comparative Development: An Empirical Investigation. American Economic Review 91, 1369-1401.

Acemoglu, D., Johnson, S., Robinson, A., 2002. Reversal of Fortune: Geography and Institutions in the Making of the Modern World Income Distribution. Quarterly Journal of Economic 117, 1231-1294.

Adelman, I., Morris, C. T., 1965. A Factor Analysis of the Interrelationship Between Social and Political Variables and Per Capita Gross National Product. Quarterly Journal of Economics 79, 555-578.

Adelman, I., Morris, C. T., 1967. Society, Politics and Economic Development, The Johns Hopkins Press, Baltimore.

Aghion, P., Howitt, P., 1992. A Model of Growth through Creative Destruction. Econometrica 60, 323-351.

Aghion, P., Howitt, P., 1998. Endogenous Growth Theory, The MIT Press, Cambridge, MA.

Alesina, A., Devleeschauwer, A., Easterly, W., Kurlat, S., Wacziarg, R., 2003. Fractionalization. Journal of Economic Growth 8, 155-194.

Archibugi, D., Coco, A., 2005. Measuring technological capabilities at the country level: A survey and a menu for choice. Research Policy 34, 175-194.

Barro, R. J., 1991. Economic Growth in a Cross Section of Countries. Quarterly Journal of Economics 106, 407-443.

Barro, R. J., 1996. Democracy and Growth. Journal of Economic Growth 1, 1-27.

Barro, R. J., Sala-i-Martin, X., 2003. Economic Growth, $2^{\text {nd }}$ edition, The MIT Press Cambridge, MA.

Basilevsky, A., 1994. Statistical Factor Analysis and Related Methods: Theory and Applications, John Wiley \& Sons Inc., London.

Baumol, W. J., Batey Blackman, S. A., Wolff, E. N., 1989. Productivity and American Leadership: The Long View, The MIT Press, Cambridge, MA.

Beck, T., Clarke, G., Groff, A., Keefer, P., Walsh, P., 2001. New Tools in Comparative Political Economy: The Database of Political Institutions. The World Bank Economic Review 15, 165-176.

Benhabib, J., Spiegel, M. M., 1994. The Role of Human Capital in Economic Development: Evidence from Aggregate Cross-country Data. Journal of Monetary Economics 34, 143173.

Bloom, D. E., Canning, D., Sevilla. J., 2003. Geography and Poverty Traps. Journal of Economic Growth 8, 355-378.

Botero, J. C., Djankov, S., La Porta, R., Lopez-de-Silanes, F., Shleifer, A., 2004. The Regulation of Labor. Quarterly Journal of Economics 119, 1339-1382. 
Chandler, A. D., 1977. The Visible Hand: The Managerial Revolution in American Business, Harvard University Press, Cambridge (MA).

Chandler, A. D., 1990. Scale and Scope: The Dynamics of Industrial Capitalism, Harvard University Press, Cambridge (MA).

Cincera, M., van Pottelsberghe de la Potterie., B., 2001. International R\&D Spillovers: A Survey. Cahiers Economiques de Bruxelles 169, 3-32.

Coe, D., Helpman., E., 1995. International R\&D Spillovers. European Economic Review 39, 859-887.

Cohen, W. M., Levinthal., D. A., 1990. Absorptive Capacity: A New Perspective on Learning and Innovation. Administrative Science Quarterly 35, 128-152.

Cornwall, J., 1976. Diffusion, Convergence and Kaldor's Law. Economic Journal 85, 307314.

Djankov, S., La Porta, R., Lopez-de-Silanes, F., Shleifer, A., 2002. The Regulation of Entry. Quarterly Journal of Economics 117, 1-37.

Djankov, S., La Porta, R., Lopez-de-Silanes, F., Shleifer, A., 2003. Courts. Quarterly Journal of Economics 118, 453-517.

Dosi, G., Pavitt, K., Soete, L. G., 1990. The economics of technical change and international trade, Harvester Whetsheaf, London.

Dunning, J. H., Narula, R., 2000. Industrial Development, Globalization and Multinational Enterprises: New Realities for Developing Countries. Oxford Development Studies 28, 141-167.

Edquist, C., 1997. Systems of Innovation: Technologies, Institutions and Organizations, Pinter, London.

Edquist, C., 2004. Systems of Innovation: Perspectives and Challenges, in Fagerberg, J., Mowery, D., Nelson, R. (Eds.), The Oxford Handbook of Innovation. Oxford University Press, Oxford, pp. 181-208.

Fabrigar, L. R., Wegener, D. T, MacCallum, R. C., Strahan, E. J., 1999. Evaluating the Use of Exploratory Factor Analysis in Psychological Research. Psychological Methods 4, 272-299.

Fagerberg, J., 1987. A Technology Gap Approach to Why Growth Rates Differ. Research Policy 16, 87-99.

Fagerberg, J., 1988. International Competitiveness. Economic Journal 98, 355-374.

Fagerberg, J., 1994. Technology and International Differences in Growth Rates. Journal of Economic Literature 32, 1147-1175.

Fagerberg, J., Godinho, M. M., 2004. Innovation and Catching-up, in Fagerberg, J., Mowery, D., Nelson, R. (Eds.), The Oxford Handbook of Innovation. Oxford University Press, Oxford, pp. 514-544.

Fearon, J. D., 2003. Ethnic and Cultural Diversity by Country. Journal of Economic Growth 8, 195-222.

Freeman, C., Clark, J., Soete, L. G., 1982. Unemployment and Technical Innovation: a Study of Long Waves and Economic Development. Pinter, London.

Freeman, C., 1987. Technology Policy and Economic Performance: Lessons from Japan, Pinter, London.

Furman, J. L., Porter, M. E., Stern, S., 2002. The determinants of national innovative capacity. Research Policy 31, 899-933.

Furman, J. L., Hayes, R., 2004. Catching up or standing still? National innovative productivity among 'follower' countries. Research Policy 33, 1329-1354. 
Gallup, J. L., Sachs, J. D., Mellinger, A., 1999. Geography and Economic Development, Harvard University, CID Working Paper no. 1/1999.

Gerschenkron, A., 1962. Economic Backwardness in Historical Perspective, The Belknap Press, Cambridge(MA).

Glaeser, E. L., La Porta, R. Lopez-de-Silanes, F., Schleifer, A., 2004. Do Institutions Cause Growth? Journal of Economic Growth 9, 271-303.

Grossman, G. M., Helpman., E., 1991. Innovation and Growth in the Global Economy, The MIT Press, Cambridge (MA).

Gwartney, J., Lawson, R., 2004. Economic Freedom of the World: 2004 Annual Report. Vancouver: The Fraser Institute. Data retrieved from www.freetheworld.com.

Henisz, W. J., 2002. The Institutional Environment for Infrastructure Investment. Industrial and Corporate Change 11, 355-389.

Henisz, W. J., 2005. POLCON Database 2005. Wharton School of the University of Pennsylvania, Philadelphia.

Johnson, A., Jacobsson, S., 2003. The Emergence of a Growth Industry: A Comparative Analysis of the German, Dutch and Swedish Wind Turbine Industries, in Metcalfe, S., Cantner, U. (Eds.), Transformations and Development: Schumpeterian Perspectives. Physical/Springer, Heidelberg.

Kaufmann, D., Kraay, A., Mastruzzi, M., 2003. Governance Matters III: Governance Indicators for 1996-2002, World Bank, New York, Policy Research Working Paper No. 3106.

Keefer, P., 2005. Database of Political Institutions: Changes and Variable Definitions. World Bank, New York, Development Research Group.

Keller, W., 2004. International Technology Diffusion. Journal of Economic Literature 42, 752-782.

King, R. G., Levine., R., 1993. Finance and Growth: Schumpeter Might be Right. Quarterly Journal of Economics 108, 717-737.

Kim, L., 1997. Imitation to Innovation: The Dynamics of Kerea's Technological Learning, Harvard Business School Press, Harvard.

Krueger, A., Lindahl., M., 2001. Education for growth: Why and for whom? Journal of Economic Literature 39, 1101-1136.

La Porta, R., López-de-Silanes, F., Pop-Eleches, C., Schleifer, A., 2004. Judicial Checks and Balances. Journal of Political Economy 112, 445-470.

Levine, R., 1997. Financial Development and Economic Growth: Views and Agenda. Journal of Economic Literature 35, 688-726.

Levine, R., Zervos, S., 1998. Stock Markets, Banks, and Economic Growth. American Economic Review 88, 537-558.

Liu, X., White, S., 2001. Comparing Innovation Systems: A Framework and Application to China's Transitional Context. Research Policy 30, 1091-1114.

Lucas, R. E., 1988. On the Mechanics of Economic Development. Journal of Monetary Economics 22, 3-42.

Lundvall, B. A., 1992. National Systems of Innovation: Towards a Theory of Innovation and Interactive Learning, Pinter Publishers, London.

Lundvall, B. A., 2003. National Innovation Systems: History and Theory, in Hanusch, H., Pyka, A. (Eds.), Companion to Neo-Schumpeterian Economics. Edward Elgar, Cheltenham.

Lundvall, B. A., Intarakumnerd, P., Vang, J., 2006. Asia's Innovation Systems in Transition. 
Edward Elgar, Cheltenham.

Mahalanobis, P. C., 1936. On the generalised distance in statistics. Proceedings of the National Institute of Science of India 12, 49-55.

Marshall, M. G., Jaggers, K., 2003. Polity IV Dataset (Computer file; version p4v2003), Center for International Development and Conflict Management, College Park (MD), University of Maryland.

Masters, W. A., McMillan, M. S., 2001. Climate and Scale in Economic Growth. Journal of Economic Growth 6, 167-186.

Muchie, M., Gammeltoft, P., Lundvall, B. Å., 2003. Putting Africa first: The making of African innovation systems, Aalborg, Aalborg University Press.

Nelson, R., Phelps, E. S., 1966. Investment in Humans, Technological Diffusion, and Economic Growth. American Economic Review 56, 69-75

Nelson, R., 1993. National Innovation Systems: A Comparative Analysis. Oxford University Press, New York.

Nonaka, I., Takeuchi, H., 1995. The Knowledge-Creating Company: How Japanese Companies Create the Dynamics of Innovation. Oxford University Press, Oxford.

Ohkawa, K., Rosovsky, H., 1973. Japanese Economic Growth, Stanford University Press, Stanford.

Rodrik, D., Subramanian, A., Trebbi, F., 2004. Institutions Rule: The Primacy of Institutions Over Geography and Intergration in Economic Development. Journal of Economic Growth 9, 131-165.

Romer, P. M., 1986. Increasing Returns and Long-run Growth. Journal of Political Economy 94, 1002-1037.

Romer, P. M., 1990. Endogenous Technological Change. Journal of Political Economy 98, 71-102.

Sachs, J. D., Warner, M., 2001. The curse of natural resources. European Economic Review 45, 827-838.

Sachs, J. D., McArthur, J. W., Schmidt-Traub, G., Kruk, M., Bahadur, C., Faye, M., McCord, G., 2004. Ending Africa's Poverty Trap. Brookings Papers on Economic Activity, 117-240.

Schumpeter, J., 1934. The Theory of Economic Development. Harvard University Press, Cambridge, (MA).

Schumpeter, J., 1943. Capitalism, Socialism and Democracy, Harper, New York.

Solow, R. M., 1956. A Contribution to the Theory of Economic Growth. Quarterly Journal of Economics 70, 65-94.

Temple, J., Johnson, P. A., 1998. Social Capability and Economic Growth. Quarterly Journal of Economics 113, 965-990.

Verspagen, B., 1991. A New Empirical Approach to Catching up or Falling Behind. Structural Change and Economic Dynamics 2, 359-380.

Viotti, E. B., 2002. National Learning Systems A new approach on technological change in late industrializing economies and evidences from the cases of Brazil and South Korea. Technological Forecasting \& Social Change 69, 653-680.

Wade, R., 1990. Governing the market: Economic theory and the role of government in East Asian industrialization. Princeton University Press, Princeton.

Woolcock, M., Narayan, D., 2000. Social Capital: Implications for Development Theory, Research, and Policy. World Bank Research Observer 15, 225-250.

Wooldridge, J. M., 2002. Econometric Analysis of Cross Section and Panel Data, The MIT 
Press, Cambridge (MA).

Wooldridge, J. M., 2003. Introductory Econometrics: A Modern Approach, $2^{\text {nd }}$ edition, Thomson South-Western College Publishing, Mason.

$\mathrm{Xu}$, B., 2000. Multinational enterprises, technology diffusion, and host country productivity growth. Journal of Development Economics 62, 477-493. 


\section{Appendix 1 (data \& sources)}

A brief overview of definitions, sources and time/country coverage of the indicators is given in the table below. The main source of data is the World Bank (World Development Indicators 2006), which combines various sources of data for a large sample of countries. The database has been complemented by data from other organizations such as UNESCO, UNCTAD, ISO, ITU, Heritage Foundation and others, and in addition datasets produced by research projects. National sources were only used for Taiwan if necessary.

We originally collected data for all independent states (app. 175 countries) and a large pool of indicators (app. 100 indicators). The screening revealed that a group of (mostly least developed) countries suffers from a lot of missing data. Similarly data for a large number of relevant indicators are available only for a group of high (medium) income countries and/or only for the most recent period. A closer look, furthermore, revealed that some indicators suffer from high volatility (primarily in developing world), methodological changes over the period or are merely variations of each other. These indicators were then skipped. In order to strike a balance between the need to bring rich evidence for as many countries as possible and data availability and methodological coherence, we selected 115 countries (see Appendix 2 for the full list of countries) and twenty-five indicators on capabilities (plus the fourteen „exogenous factors“ reflecting differences in geography, nature and history). We use the indicators in the form of three-year averages (1992-1994 and 2002-2004) to limit influence of shocks and measurement errors occurring in specific years.

Although the selected indicators have broad coverage, in some cases there were missing values that had to be dealt with. Missing values were most frequent for personal computers, the teacher-pupil ratio, market capitalization of listed companies and some of the governance indicators. A number of developing countries were not included in the early surveys of computers and Internet penetration. We assumed that the initial value was zero if these series started from less than one per mil. people later during the nineties (six observations for computers and eighteen observations for Internet). Some missing data on the market capitalization were filled by collecting information on Stock Markets of the World (www.escapeartist.com/stock/markets.htm). Countries without a stock market in a given period were given zero (a total of forty-five observations). The remaining missing data were estimated using the impute procedure in Stata 9.2 (see the Stata 9 Manual for details). We based the estimation on data for other indicators in the dataset. The proportion of data estimated by the procedure is given in the last column of the following table.

It should be stressed that considerable care was taken to check the estimated data against observed figures in countries with similar characteristics (level of development, region, history, etc.). In a few cases the estimated data would exceed the minimum observed value of an indicator elsewhere. In such cases we truncated the data by replacing the estimated values by the minimum observed figure. Only data from 1993 onwards were used for the science and engineering articles for the former Soviet Union and Yugoslavia countries due to problems of reporting in the early 1990s. We also reversed the scale, while keeping the original range, for some indicators of governance and political system in order to have the indicator in increasing order (with low value signalling weak governance and vice versa). Note that this change of scale does not alter any property of the data but simplifies the interpretation of loadings in the factor analysis. 


\begin{tabular}{|c|c|c|c|c|}
\hline Indicator \& definition & Scaling & Source & $\begin{array}{c}\text { Average } \\
\text { over period }\end{array}$ & $\begin{array}{l}\% \text { of data } \\
\text { estimated }\end{array}$ \\
\hline $\begin{array}{l}\text { Gross Domestic Product (GDP): GDP converted to (constant 2000) } \\
\text { international USD using purchasing power parity rates (PPP). }\end{array}$ & per capita & $\begin{array}{l}\text { World Bank (World Development Indicators } \\
\text { 2006) }\end{array}$ & $\begin{array}{l}1992-1994 \\
\& \\
2002-2004\end{array}$ & 0 \\
\hline $\begin{array}{l}\text { USPTO patents: Number of utility patents (patents for invention) granted by } \\
\text { the U.S. Patent and Trademark Office (USPTO). The origin of a patent is } \\
\text { determined by the residence of the first-named inventor. }\end{array}$ & per capita & USPTO & $\begin{array}{l}1992-1994 \\
\& \\
2002-2004\end{array}$ & 0 \\
\hline $\begin{array}{l}\text { Science } \& \text { engineering articles: Counts of articles published in journals } \\
\text { classified and covered by Science Citation Index (SCI) and Social Sciences } \\
\text { Citation Index (SSCI). The article counts are based on fractional } \\
\text { assignments. }\end{array}$ & per capita & $\begin{array}{l}\text { U.S. National Science Foundation (Science } \\
\text { and Engineering Indicators 2006) }\end{array}$ & $\begin{array}{l}1992-1994 \\
\& \\
2002-2003\end{array}$ & 0 \\
\hline $\begin{array}{l}\text { ISO } 9000 \text { certifications: A family of standards approved by the } \\
\text { International Standards Organization (ISO) that define a quality management } \\
\text { and quality assurance program. }\end{array}$ & per capita & $\begin{array}{l}\text { International Organization for Standardization } \\
\text { (The ISO Surveys of ISO } 9000 \text { Certificates) }\end{array}$ & $\begin{array}{l}1992-1994 \\
\& \\
2002-2003\end{array}$ & 0 \\
\hline $\begin{array}{l}\text { Fixed line and mobile phone subscribers: Telephone mainlines connecting } \\
\text { a customer's equipment to the public switched telephone network (PSTN) } \\
\text { and users of portable telephones that subscribe to an automatic public mobile } \\
\text { telephone service by cellular technology providing access to the PSTN. }\end{array}$ & per capita & $\begin{array}{l}\text { World Bank (World Development Indicators } \\
\text { 2006), ITU (World Telecommunication } \\
\text { Indicators Database 2005) }\end{array}$ & $\begin{array}{l}1992-1994 \\
\& \\
2002-2004\end{array}$ & 0 \\
\hline $\begin{array}{l}\text { Internet users: Internet users are people with access to the worldwide } \\
\text { network. }\end{array}$ & per capita & $\begin{array}{l}\text { World Bank (World Development Indicators } \\
\text { 2006), ITU (World Telecommunication } \\
\text { Indicators Database 2005) }\end{array}$ & $\begin{array}{c}1994 \\
\& \\
2002-2004\end{array}$ & 1 \\
\hline Personal computers: Computers designed to be used by a single individual. & per capita & $\begin{array}{l}\text { World Bank (World Development Indicators } \\
\text { 2006), ITU (World Telecommunication } \\
\text { Indicators Database 2005) }\end{array}$ & $\begin{array}{c}1994 \\
\& \\
2002-2004\end{array}$ & 9 \\
\hline $\begin{array}{l}\text { Primary school teacher-pupil ratio: The number of primary school } \\
\text { teachers (regardless of their teaching assignment) divided by the number of } \\
\text { pupils enrolled in primary school. }\end{array}$ & ratio & $\begin{array}{l}\text { World Bank (World Development Indicators } \\
\text { 2006), UNESCO (Global Education Digest } \\
\text { 2005) }\end{array}$ & $\begin{array}{c}1991 \\
\& \\
2002-2004\end{array}$ & 11 \\
\hline $\begin{array}{l}\text { Secondary school enrolment: The ratio of the number of secondary students } \\
\text { of all ages (gross) expressed as a percentage of the secondary school-age } \\
\text { population. }\end{array}$ & $\%$ gross & $\begin{array}{l}\text { World Bank (World Development Indicators } \\
\text { 2006), UNESCO (Global Education Digest } \\
\text { 2005) }\end{array}$ & $\begin{array}{c}1991 \\
\& \\
2002-2004\end{array}$ & 3 \\
\hline $\begin{array}{l}\text { Tertiary school enrolment: The ratio of the number of tertiary students of } \\
\text { all ages (gross) expressed as a percentage of the tertiary school-age } \\
\text { population. }\end{array}$ & $\%$ gross & $\begin{array}{l}\text { World Bank (World Development Indicators } \\
\text { 2006), UNESCO (Global Education Digest } \\
\text { 2005) }\end{array}$ & $\begin{array}{c}1991 \\
\& \\
2002-2004\end{array}$ & 3 \\
\hline
\end{tabular}


Domestic credit to private sector: Financial resources provided to the private sector, such as through loans, purchases of nonequity securities, and trade credits and other accounts receivable, that establish a claim for

\% of GDP World Bank (World Development Indicators

Market capitalization of listed companies: The share price times the number of shares outstanding (also known as market value) of domestically incorporated companies listed on the country's stock exchanges at the end of

World Bank (World Development Indicators 2006)
1992-1994

\&

2002-2004

1992-1994 \%orld Bank (World Development Indicators
2006)

Merchandise imports: The c.i.f. value of goods received from the rest of the world. Goods simply being transported through a country (good in transit) or temporarily admitted (except for goods for inward processing) are not included.

Foreign direct investment (FDI) inward stock: A received investment that involves a long-term relationship and reflects a lasting interest in and control by a resident entity in one economy of an enterprise resident in a different $\%$ of GDP UNCTAD (FDI Database 2005)

1992-1994 economy.

Impartial courts: The degree to which a trusted legal framework exists for private businesses to challenge the legality of government actions or regulation.

index Gwartney and Lawson (2004) - based on the

(0 to 10$)$ WEF (Global Competitiveness Report,

various issues)

Law and order: The degree to which the citizens of a country are willing to accept the established institutions, to make and implement laws and adjudicate disputes.

Property rights: The degree to which a country's laws protect private property rights and the degree to which its government enforces those laws. The scale of the indicator has been reversed into increasing order, while keeping its original range.

Regulation: How easy or difficult it is to open and operate a business. The scale of the indicator has been reversed into increasing order, while keeping its original range.

Informal Market: The perceptions of people with regard to the extent of corruption, defined as the misuse of public power for private benefit. The scale of the indicator has been reversed into increasing order, while keeping its original range.
PRS Group (International Country Risk

Guide, various issues) - data retrieved from Henisz (2005)

Heritage Foundation (Index of Economic

index Freedom, various issues) - based on the

(1 to 5) Economist Intelligence Unit (Country

Heritage Foundation (Index of Economic

index Freedom, various issues) - based on the

(1 to 5) Economist Intelligence Unit (Country Commerce and Country Reports)

Heritage Foundation (Index of Economic

index Freedom, various issues) - based on the

(1 to 5) Transparency International (Corruption Perceptions Index) Commerce and Country Reports) 


\begin{tabular}{|c|c|c|c|c|}
\hline $\begin{array}{l}\text { Index of democracy and autocracy: The degree of democracy versus } \\
\text { autocracy (POLITY2 variable in increasing order from autocracy to } \\
\text { democracy). }\end{array}$ & $\begin{array}{l}\text { index } \\
(-10 \text { to } 10)\end{array}$ & Marshall and Jaggers (2003) & $\begin{array}{l}1992-1994 \\
\& \\
2002-2003\end{array}$ & 0 \\
\hline $\begin{array}{l}\text { Political constraint: The extent to which a change in the preferences of any } \\
\text { one actor may lead to a change in government policy (POLCONIII variable). }\end{array}$ & $\begin{array}{l}\text { index } \\
(0 \text { to } 1)\end{array}$ & Henisz $(2002,2005)$ & $\begin{array}{l}1992-1994 \\
\& \\
2002-2004\end{array}$ & 0 \\
\hline $\begin{array}{l}\text { Legislative index of political competitiveness: Competitiveness of elections } \\
\text { into legislative branches (LIEC variable ). }\end{array}$ & $\begin{array}{l}\text { index } \\
(1 \text { to } 7)\end{array}$ & Beck et al. (2001) and Keefer (2005) & $\begin{array}{l}1992-1994 \\
\& \\
2002-2004\end{array}$ & 0 \\
\hline $\begin{array}{l}\text { Executive index of political competitiveness: Competitiveness for post in } \\
\text { executive branches in government (EIEC variable). }\end{array}$ & $\begin{array}{l}\text { index } \\
(1 \text { to } 7)\end{array}$ & Beck et al. (2001) and Keefer (2005) & $\begin{array}{l}1992-1994 \\
\& \\
2002-2004 \\
\end{array}$ & 0 \\
\hline $\begin{array}{l}\text { Political rights: The degree to which people participate freely in the political } \\
\text { process derived from standards by the Universal Declaration of Human } \\
\text { Rights. The scale of the indicator has been reversed into increasing order, } \\
\text { while keeping its original range. }\end{array}$ & $\begin{array}{l}\text { index } \\
(1 \text { to } 7)\end{array}$ & $\begin{array}{l}\text { Freedom House (Index of Freedom in the } \\
\text { World, various issues) }\end{array}$ & $\begin{array}{l}1992-1994 \\
\& \\
2002-2004\end{array}$ & 0 \\
\hline $\begin{array}{l}\text { Civil liberties: The degree of the freedoms of expression and belief, } \\
\text { associational and organizational rights, rule of law, and personal autonomy } \\
\text { without interference from the state derived from standards by the Universal } \\
\text { Declaration of Human Rights. The scale of the indicator has been reversed } \\
\text { into increasing order, while keeping its original range. }\end{array}$ & $\begin{array}{l}\text { index } \\
(1 \text { to } 7)\end{array}$ & $\begin{array}{l}\text { Freedom House (Index of Freedom in the } \\
\text { World, various issues) }\end{array}$ & $\begin{array}{l}1992-1994 \\
\& \\
2002-2004\end{array}$ & 0 \\
\hline $\begin{array}{l}\text { Longitude of country centroid: Longitude is measured from the Prime } \\
\text { Meridian with positive values going east and negative values going west. }\end{array}$ & degrees & $\begin{array}{l}\text { Gallup et al. (1999) - CID Geography } \\
\text { Datasets }\end{array}$ & $\begin{array}{l}\text { Fixed } \\
\text { factor }\end{array}$ & 0 \\
\hline $\begin{array}{l}\text { Latitude of country centroid: Latitude is measured from the equator, with } \\
\text { positive values going north and negative values going south. }\end{array}$ & degrees & $\begin{array}{l}\text { Gallup et al. (1999) - CID Geography } \\
\text { Datasets }\end{array}$ & $\begin{array}{l}\text { Fixed } \\
\text { factor }\end{array}$ & 0 \\
\hline $\begin{array}{l}\text { Surface area: Country's total area, including areas under inland bodies of } \\
\text { water and some coastal waterways. }\end{array}$ & $\begin{array}{c}\text { Log of } \\
\mathrm{km}^{2}\end{array}$ & $\begin{array}{l}\text { World Bank (World Development Indicators } \\
\text { 2006) }\end{array}$ & $\begin{array}{l}\text { Fixed } \\
\text { factor }\end{array}$ & 0 \\
\hline $\begin{array}{l}\text { Access to ocean: Proportion of land within } 100 \mathrm{~km} \text { of the ocean coastline, } \\
\text { excluding coastline in the arctic and sub-arctic region above the winter extent } \\
\text { of sea ice. }\end{array}$ & $\%$ & $\begin{array}{l}\text { Gallup et al. (1999) - CID Geography } \\
\text { Datasets }\end{array}$ & $\begin{array}{l}\text { Fixed } \\
\text { factor }\end{array}$ & 0 \\
\hline $\begin{array}{l}\text { Land in desert ecozone: Proportion of land in (temperate or tropical) desert } \\
\text { ecozone. }\end{array}$ & $\%$ & $\begin{array}{l}\text { Gallup et al. (1999) - CID Geography } \\
\text { Datasets - based on the UNEP }\end{array}$ & $\begin{array}{l}\text { Fixed } \\
\text { factor }\end{array}$ & 0 \\
\hline Land in tropical ecozone: Proportion of land in tropical ecozone. & $\%$ & $\begin{array}{l}\text { Gallup et al. (1999) - CID Geography } \\
\text { Datasets - based on the UNEP }\end{array}$ & $\begin{array}{l}\text { Fixed } \\
\text { factor }\end{array}$ & 0 \\
\hline
\end{tabular}




\begin{tabular}{|c|c|c|c|c|}
\hline Population density: Midyear population divided by land area. & $\begin{array}{l}\text { Log of } \\
\text { people per } \\
\mathrm{km}^{2}\end{array}$ & $\begin{array}{l}\text { World Bank (World Development Indicators } \\
\text { 2006); missing data filled from UNEP (The } \\
\text { GEO Data Portal) }\end{array}$ & $1992-2004$ & 0 \\
\hline $\begin{array}{l}\text { Malaria fatal risk: Proportion of population at risk of contracting } \\
\text { falciparum malaria. }\end{array}$ & $\%$ & $\begin{array}{l}\text { Earth Institute (Jeffrey D. Sachs Malaria } \\
\text { Dataset) }\end{array}$ & 1996 & 0 \\
\hline $\begin{array}{l}\text { Ethnic fractionalization: The probability that two randomly selected people } \\
\text { from a given country will not belong to the same ethic group. }\end{array}$ & $\begin{array}{l}\text { index } \\
(0 \text { to } 1)\end{array}$ & Alesina et al. (2003) & $\begin{array}{l}\text { The latest } \\
\text { available }\end{array}$ & 0 \\
\hline $\begin{array}{l}\text { Religion fractionalization: The probability that two randomly selected } \\
\text { people from a given country will not belong to the same religion. }\end{array}$ & $\begin{array}{l}\text { index } \\
(0 \text { to } 1)\end{array}$ & Alesina et al. (2003) & $\begin{array}{l}\text { The latest } \\
\text { available }\end{array}$ & 0 \\
\hline Oil deposits: Proven crude oil reserves in billion barrels (bbl). & $\begin{array}{c}\text { log of } \\
(\mathrm{bbl}+1) \\
\text { per capita }\end{array}$ & The CIA World Factbook 2005 & $\begin{array}{l}\text { The latest } \\
\text { available }\end{array}$ & 0 \\
\hline $\begin{array}{l}\text { Killed in natural disasters: Number of persons killed (confirmed as dead, } \\
\text { missing and presumed dead) in disasters of natural origin (droughts, } \\
\text { earthquakes, extreme temperatures, floods, slides, waves, wind storms, etc.). }\end{array}$ & $\begin{array}{l}\text { log of } \\
\text { killed per } \\
\text { capita }\end{array}$ & $\begin{array}{l}\text { UNEP (The GEO Data Portal) - based on the } \\
\text { OFDA/CRED International Disaster Database } \\
2004\end{array}$ & $1992-2004$ & 0 \\
\hline $\begin{array}{l}\text { National independence: Number of years since gaining national } \\
\text { independence over the period 1816-2004 (maximum truncated at } 188 \text { years). }\end{array}$ & $\begin{array}{l}\text { Log of } \\
\text { years }\end{array}$ & $\begin{array}{l}\text { Fearon (2003); missing data filled from the } \\
\text { CIA World Factbook }\end{array}$ & $1816-2004$ & 0 \\
\hline
\end{tabular}




\begin{tabular}{|c|c|c|c|c|c|c|c|c|}
\hline & \multicolumn{2}{|c|}{$\begin{array}{c}\text { Innovation } \\
\text { system }\end{array}$} & \multicolumn{2}{|c|}{ Governance } & \multicolumn{2}{|c|}{ Political system } & \multicolumn{2}{|c|}{ Openness } \\
\hline & 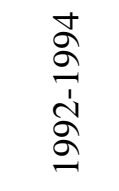 & $\begin{array}{l}\text { d } \\
\stackrel{1}{1} \\
\stackrel{1}{8} \\
\stackrel{d}{0}\end{array}$ & 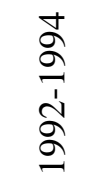 & 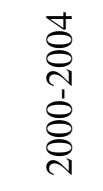 & 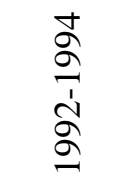 & 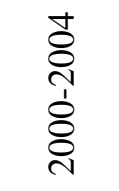 & 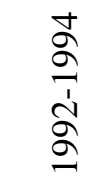 & 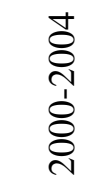 \\
\hline \multicolumn{9}{|c|}{$\underline{\text { Developed Countries }}$} \\
\hline Australia & 0.90 & 1.62 & 1.38 & 1.43 & 0.82 & 0.78 & 0.37 & 0.67 \\
\hline Austria & 0.98 & 1.31 & 1.39 & 1.29 & 0.73 & 0.79 & -0.85 & 0.35 \\
\hline Belgium & 0.86 & 1.43 & 1.28 & 0.96 & 0.85 & 0.84 & 0.62 & 1.38 \\
\hline Canada & 1.01 & 1.26 & 1.63 & 1.40 & 0.76 & 0.78 & 0.67 & 1.48 \\
\hline Denmark & 0.97 & 1.57 & 1.60 & 1.67 & 0.81 & 0.81 & -0.89 & 0.10 \\
\hline Finland & 1.11 & 1.42 & 1.23 & 1.49 & 0.79 & 0.83 & -0.82 & 0.35 \\
\hline France & 1.06 & 1.30 & 1.19 & 0.86 & 0.66 & 0.82 & -0.60 & 0.43 \\
\hline Germany & 0.93 & 1.34 & 1.62 & 1.28 & 0.71 & 0.79 & -0.96 & 0.11 \\
\hline Greece & 0.53 & 1.26 & 0.60 & 0.15 & 0.65 & 0.68 & -0.83 & -0.34 \\
\hline Ireland & 0.55 & 1.24 & 1.33 & 1.28 & 0.80 & 0.82 & 0.96 & 1.25 \\
\hline Israel & 0.89 & 1.47 & 1.00 & 0.90 & 0.67 & 0.69 & -1.13 & -0.05 \\
\hline Italy & 0.85 & 1.50 & 1.00 & 0.44 & 0.71 & 0.75 & -1.34 & -0.28 \\
\hline Japan & 0.94 & 1.44 & 1.53 & 0.78 & 0.77 & 0.82 & -3.23 & -1.77 \\
\hline Netherlands & 0.98 & 1.45 & 1.63 & 1.38 & 0.83 & 0.75 & 0.17 & 1.20 \\
\hline New Zealand & 0.90 & 1.33 & 1.63 & 1.46 & 0.74 & 0.83 & 0.19 & 0.53 \\
\hline Norway & 1.01 & 1.51 & 1.41 & 1.24 & 0.80 & 0.81 & -0.41 & -0.24 \\
\hline Portugal & 0.44 & 1.30 & 0.91 & 0.69 & 0.72 & 0.74 & -0.13 & 0.46 \\
\hline Spain & 0.60 & 1.38 & 0.89 & 0.61 & 0.78 & 0.81 & -0.55 & 0.55 \\
\hline Sweden & 1.17 & 1.61 & 1.41 & 1.34 & 0.74 & 0.80 & -0.56 & 0.70 \\
\hline Switzerland & 1.05 & 1.48 & 1.38 & 1.40 & 0.85 & 0.86 & -0.35 & 0.46 \\
\hline United Kingdom & 0.88 & 1.50 & 1.83 & 1.49 & 0.70 & 0.77 & -0.11 & 0.26 \\
\hline United States & 1.09 & 1.47 & 1.70 & 1.49 & 0.80 & 0.79 & -0.74 & 0.03 \\
\hline \multicolumn{9}{|c|}{ Asian Tigers } \\
\hline Korea & 0.46 & 1.23 & 0.88 & 0.53 & 0.62 & 0.70 & -1.13 & -0.01 \\
\hline Singapore & 0.59 & 1.22 & 1.51 & 1.51 & -0.56 & -0.53 & 1.45 & 1.85 \\
\hline Taiwan & 0.61 & 1.31 & 1.59 & 0.79 & -0.16 & 0.69 & -0.64 & 0.17 \\
\hline \multicolumn{9}{|c|}{ New EU Members } \\
\hline Czech Republic & 0.31 & 1.08 & 0.73 & 0.16 & 0.74 & 0.73 & 0.06 & 1.28 \\
\hline Estonia & 0.15 & 1.12 & 0.65 & 0.70 & 0.07 & 0.67 & -0.51 & 1.59 \\
\hline Hungary & 0.34 & 1.21 & 0.97 & 0.40 & 0.69 & 0.69 & -0.49 & 1.16 \\
\hline Latvia & -0.03 & 1.03 & 0.06 & -0.02 & 0.26 & 0.69 & -1.14 & 0.59 \\
\hline Lithuania & -0.03 & 0.99 & 0.11 & -0.17 & 0.17 & 0.70 & -1.04 & 0.78 \\
\hline Poland & 0.17 & 1.10 & 0.42 & -0.10 & 0.48 & 0.73 & -1.26 & 0.48 \\
\hline Slovakia & 0.18 & 0.94 & 0.92 & -0.11 & -0.01 & 0.74 & -0.64 & 1.19 \\
\hline Slovenia & 0.54 & 1.36 & 0.02 & 0.47 & 0.69 & 0.77 & -0.49 & 0.16 \\
\hline
\end{tabular}




\begin{tabular}{|c|c|c|c|c|c|c|c|c|}
\hline \multicolumn{9}{|c|}{ West Asia } \\
\hline Bahrain & 0.28 & 0.84 & 1.68 & 1.19 & -3.05 & -2.43 & 0.21 & 0.42 \\
\hline Iran & -0.48 & 0.61 & -1.31 & -1.99 & -1.69 & -0.75 & -0.81 & -0.62 \\
\hline Jordan & -0.32 & 0.66 & 0.84 & 0.39 & -0.60 & -0.94 & 0.01 & 1.02 \\
\hline Kuwait & 0.06 & 1.03 & 1.46 & 0.97 & -1.33 & -1.11 & -2.41 & -1.82 \\
\hline Oman & -0.69 & 0.35 & 1.42 & 0.74 & -2.63 & -2.43 & -0.06 & 0.49 \\
\hline Saudi Arabia & 0.03 & 1.00 & 1.44 & 0.39 & -3.75 & -3.60 & 0.02 & -0.05 \\
\hline Syria & -0.73 & 0.17 & -0.65 & -1.37 & -2.47 & -1.79 & -0.93 & -0.06 \\
\hline Turkey & -0.32 & 0.64 & 0.26 & -0.54 & 0.39 & 0.38 & -0.78 & 0.47 \\
\hline United Arab Emirates & 0.18 & 0.98 & 1.60 & 1.07 & -2.82 & -2.87 & -0.09 & 0.22 \\
\hline \multicolumn{9}{|c|}{$\underline{\text { Latin America }}$} \\
\hline Argentina & 0.20 & 1.06 & 0.43 & -1.09 & 0.66 & 0.69 & -1.45 & 0.15 \\
\hline Bolivia & -0.63 & 0.44 & -0.79 & -1.53 & 0.57 & 0.61 & -0.28 & 1.07 \\
\hline Brazil & -0.12 & 0.67 & 0.28 & -0.28 & 0.58 & 0.71 & -0.95 & 0.24 \\
\hline Chile & -0.01 & 0.63 & 1.15 & 0.92 & 0.69 & 0.81 & 0.22 & 1.31 \\
\hline Colombia & -0.26 & 0.47 & -0.68 & -1.10 & 0.58 & 0.26 & -0.70 & 0.41 \\
\hline Costa Rica & -0.20 & 0.52 & 0.33 & 0.12 & 0.75 & 0.65 & -0.07 & 0.67 \\
\hline Dominican Republic & -0.77 & -0.08 & -0.58 & -1.27 & 0.38 & 0.58 & -0.72 & 0.36 \\
\hline Ecuador & -0.50 & 0.39 & -0.58 & -1.52 & 0.42 & 0.48 & -0.69 & 0.67 \\
\hline El Salvador & -0.95 & 0.06 & -0.07 & -0.35 & 0.48 & 0.46 & -1.06 & 0.32 \\
\hline Guatemala & -1.01 & -0.01 & -0.53 & -1.63 & -0.05 & 0.31 & -0.43 & 0.25 \\
\hline Guyana & -1.11 & 0.03 & -0.56 & -0.52 & 0.47 & 0.55 & 1.08 & 2.43 \\
\hline Honduras & -1.06 & -0.12 & -0.42 & -1.33 & 0.51 & 0.50 & -0.12 & 0.89 \\
\hline Jamaica & -0.51 & 0.45 & 0.09 & -0.49 & 0.58 & 0.57 & 0.05 & 0.79 \\
\hline Mexico & -0.16 & 0.49 & 0.11 & -0.48 & 0.18 & 0.66 & -0.08 & 1.06 \\
\hline Nicaragua & -0.77 & 0.08 & -0.92 & -1.40 & 0.21 & 0.47 & -0.17 & 1.32 \\
\hline Panama & -0.26 & 0.68 & 0.13 & -0.72 & 0.55 & 0.78 & -0.06 & 0.58 \\
\hline Paraguay & -1.00 & 0.23 & -0.26 & -2.06 & 0.43 & 0.48 & -0.69 & 0.61 \\
\hline Peru & -0.35 & 0.56 & -0.99 & -1.27 & 0.01 & 0.65 & -1.38 & 0.16 \\
\hline Trinidad and Tobago & -0.21 & 0.60 & 0.90 & 0.25 & 0.88 & 0.55 & -0.64 & 0.64 \\
\hline Uruguay & -0.02 & 0.75 & 0.18 & -0.04 & 0.76 & 0.88 & -1.55 & -0.35 \\
\hline Venezuela & -0.04 & 0.89 & -0.32 & -2.52 & 0.53 & 0.50 & -0.42 & 0.23 \\
\hline \multicolumn{9}{|c|}{ East Europe \& CIS } \\
\hline Albania & -0.91 & -0.06 & -0.74 & -1.46 & 0.27 & 0.47 & -1.43 & -0.52 \\
\hline Armenia & -0.45 & 0.39 & -0.24 & -0.75 & 0.15 & 0.05 & -1.23 & 0.22 \\
\hline Belarus & -0.08 & 0.94 & -0.18 & -1.49 & -0.65 & -2.42 & -3.20 & 0.64 \\
\hline Bulgaria & 0.11 & 0.93 & 0.12 & -0.73 & 0.51 & 0.68 & -1.18 & 0.89 \\
\hline Croatia & 0.21 & 1.13 & -0.84 & -0.65 & -0.33 & 0.48 & -1.14 & 0.85 \\
\hline Georgia & -0.29 & 0.60 & -1.30 & -1.41 & -0.60 & 0.24 & -3.34 & -0.31 \\
\hline Moldova & -0.55 & 0.42 & -0.66 & -0.42 & -0.48 & 0.32 & -1.80 & 1.00 \\
\hline Romania & -0.19 & 0.80 & -0.76 & -1.07 & 0.22 & 0.58 & -1.99 & 0.70 \\
\hline Russia & 0.01 & 1.03 & -0.37 & -1.19 & -0.10 & -0.19 & -1.85 & 0.62 \\
\hline Ukraine & -0.11 & 0.76 & -1.28 & -1.15 & 0.33 & 0.18 & -2.09 & 0.67 \\
\hline
\end{tabular}




\begin{tabular}{|c|c|c|c|c|c|c|c|c|}
\hline \multicolumn{9}{|c|}{ North Africa } \\
\hline Algeria & -0.85 & -0.03 & -0.48 & -1.12 & -2.49 & -0.36 & -1.04 & 0.04 \\
\hline Egypt & -0.20 & 0.58 & -0.94 & -0.45 & -0.86 & -0.90 & -0.19 & 0.03 \\
\hline Morocco & -0.77 & 0.10 & 0.88 & 0.10 & -1.03 & -0.95 & -0.11 & 1.07 \\
\hline Tunisia & -0.57 & 0.47 & 0.77 & 0.40 & -1.43 & -1.39 & 0.88 & 1.28 \\
\hline \multicolumn{9}{|c|}{$\underline{\text { South-East Asia }}$} \\
\hline China & -0.65 & 0.64 & -0.22 & -0.42 & -2.69 & -2.39 & 0.19 & 1.17 \\
\hline Indonesia & -0.68 & 0.10 & -0.37 & -1.08 & -1.98 & 0.30 & -0.49 & -0.24 \\
\hline Malaysia & 0.03 & 0.82 & 0.94 & 0.28 & 0.08 & 0.06 & 1.67 & 2.14 \\
\hline Philippines & -0.48 & 0.31 & -0.48 & -1.13 & 0.42 & 0.54 & -0.33 & 1.09 \\
\hline Thailand & -0.33 & 0.61 & 0.79 & 0.26 & 0.00 & 0.55 & 0.48 & 1.46 \\
\hline Vietnam & -1.45 & 0.09 & -2.18 & -1.92 & -2.46 & -1.88 & -0.06 & 1.81 \\
\hline \multicolumn{9}{|c|}{$\underline{\text { Sub-Sahara Africa }}$} \\
\hline Benin & -1.99 & -1.09 & 0.22 & -0.79 & 0.55 & 0.58 & -0.17 & -0.51 \\
\hline Botswana & -1.02 & -0.09 & 0.73 & 0.69 & 0.23 & 0.49 & 0.92 & 0.93 \\
\hline Burkina Faso & -2.24 & -1.46 & -0.88 & -0.51 & -1.35 & -0.38 & -1.29 & -1.15 \\
\hline Cameroon & -1.55 & -0.69 & -0.94 & -1.48 & -0.88 & -1.09 & -1.36 & -0.36 \\
\hline Congo & -1.55 & -1.16 & -1.53 & -1.60 & -0.12 & -0.89 & -0.08 & 1.11 \\
\hline Cote d'Ivoire & -1.16 & -0.46 & 0.05 & -1.25 & -0.93 & -0.49 & -0.29 & 0.62 \\
\hline Ethiopia & -2.01 & -1.41 & -0.42 & -0.76 & -1.83 & -0.11 & -1.49 & 1.08 \\
\hline Ghana & -1.48 & -0.77 & 0.21 & -0.24 & -0.78 & 0.56 & 0.15 & 1.16 \\
\hline Guinea & -2.18 & -1.31 & 0.06 & -1.29 & -2.12 & -0.31 & -1.01 & -0.42 \\
\hline Kenya & -1.19 & -0.41 & -0.08 & -0.81 & -0.67 & 0.50 & 0.04 & 0.34 \\
\hline Madagascar & -1.91 & -1.29 & -0.80 & -0.84 & 0.38 & 0.53 & -1.27 & -0.15 \\
\hline Malawi & -2.42 & -1.47 & 0.03 & -0.19 & -1.41 & 0.32 & -0.03 & 0.92 \\
\hline Mali & -2.41 & -1.48 & -0.53 & -0.59 & 0.12 & 0.59 & -0.04 & 0.46 \\
\hline Mozambique & -2.46 & -1.52 & -0.77 & -1.17 & -1.25 & 0.38 & 0.39 & 1.82 \\
\hline Namibia & -1.02 & -0.19 & 0.79 & 0.71 & 0.50 & 0.30 & 1.42 & 1.64 \\
\hline Niger & -2.38 & -1.78 & -0.80 & -1.25 & -0.39 & 0.38 & -0.02 & 0.08 \\
\hline Nigeria & -1.37 & -0.47 & 0.02 & -1.34 & -2.03 & 0.30 & 0.67 & 0.76 \\
\hline Senegal & -1.55 & -0.85 & 0.09 & -0.50 & 0.04 & 0.52 & -0.75 & 0.70 \\
\hline South Africa & 0.21 & 0.51 & 0.71 & 0.34 & 0.31 & 0.76 & -0.32 & 1.05 \\
\hline Tanzania & -2.10 & -1.47 & 0.31 & -0.43 & -1.27 & 0.05 & 0.48 & 1.26 \\
\hline Togo & -1.67 & -0.76 & -0.70 & -1.79 & -1.41 & -0.85 & -0.66 & 0.72 \\
\hline Uganda & -1.90 & -0.99 & 0.39 & -0.44 & -1.70 & -0.72 & -1.49 & 0.32 \\
\hline Zambia & -1.38 & -1.14 & -0.39 & -0.47 & 0.26 & 0.21 & 0.61 & 1.59 \\
\hline Zimbabwe & -0.98 & -0.02 & 0.23 & -2.50 & -0.82 & -1.29 & -0.70 & 1.34 \\
\hline \multicolumn{9}{|c|}{ Central Asia } \\
\hline Bangladesh & -1.42 & -0.60 & -1.44 & -2.03 & 0.52 & 0.33 & -2.63 & -0.63 \\
\hline India & -1.01 & -0.15 & -0.03 & -0.10 & 0.43 & 0.62 & -2.16 & -0.41 \\
\hline Mongolia & -0.85 & 0.01 & 0.46 & -0.41 & 0.16 & 0.27 & 0.03 & 1.94 \\
\hline Nepal & -1.40 & -0.66 & -0.74 & -1.07 & 0.36 & -0.71 & -1.97 & -0.69 \\
\hline Pakistan & -1.28 & -0.57 & -0.44 & -0.74 & 0.36 & -1.63 & -0.80 & 0.14 \\
\hline Sri Lanka & -0.91 & 0.21 & -0.35 & -0.28 & 0.17 & 0.42 & -0.34 & 0.07 \\
\hline \multicolumn{9}{|c|}{ Oceania } \\
\hline Fiji & -0.56 & 0.40 & -0.13 & -0.39 & 0.08 & 0.33 & -0.12 & 0.21 \\
\hline Papua New Guinea & -1.47 & -0.82 & 0.43 & -0.07 & 0.58 & 0.65 & 0.63 & 1.96 \\
\hline
\end{tabular}

Note: For definition of the variables see Table 1. 